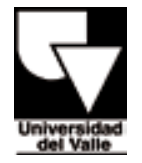
Rector Universidad del Valle
Dr. Iván Enrique Ramos Calderón Decano Facultad de Humanidades Facultad de Humanidades
Mag. Darío Henao Restrepo Director Escuela de Estudios Literarios Mag. Julián Malatesta Director Revista Poligramas Mag. Darío Henao Restrepo Comité Editorial

Mag. Carmiña Navia Velasco (Universidad del Valle) Mag. Juan Julián Jiménez Pimentel (Universidad del Valle) Dr. César Valencia Solanilla (Universidad Tecnológica de Pereira) Dra. María Antonieta Gómez Goyeneche (Universidad del Valle) Dr. Fabio Martínez Universidad del Valle) Dr. Augusto Escobar (Universidad de Antioquia) Asistente Editorial Elizabeth Vejarano
Corrección Comité Asesor
Dr. Eduardo F. Coutinho (Universidad Federal de Río de Janeiro)
r. Eduardo F. Coutinho Dra. Silvia Inés Cárcamo

(Universidad Federal de Río de Janeiro)

Dr. Michael Palencia Roth

(Universidad de Illinois)

Dr. Hernán Lara Zabala

(Universidad Autónoma de México)

Dr. Armando Romero

(Universidad de Cinccinati)

Dr. Álvaro Pineda Botero

(Universidad EAFIT)

Dr. Jaques Gillard

(Universidad de Tolouse)

Dr. Fernando Cruz Kronfly

(Universidad del Valle)

Periodicidad

Semestral

Ilustraciones

Gerardo López Caicedo

Traducciones

Simone Accorsi,

Diseño y diagramación

Unidad de Artes Gráficas

Rodolfo Villa Valencia

Facultad de Humanidade 
2 
Dossier mito y representación 


\section{El Chocó en la independencia de Colombia}

\section{Rogerio Velásquez}

"Excelentísimo señor:

En este día me da aviso Don Julián Bayer, Comandante de la Columna de Atrato, de estar sometida a la obediencia del Soberano, la Provincia del Chocó; yo creo que esta es la última que lo ha hecho de todo este Reino, y acaso de todos sus dominios en América".

\section{Introducción}

\section{Estampa breve de la tierra}

A principios del siglo XIX, la extensión superficiaria del Chocó era conocida ampliamente. Por las trochas indias o mineras, conquistadores y traficantes de toda laya habían recorrido la tierra que iba desde el Golfo de Urabá a la frontera ecuatoriana, desde el Darién panameño a los Valles de Curazamba. Picachos y Sabanas de Frontino y planadas de Nore, Sasafiral, Tres Morros y Paramillo; las quiebras de Chamí y las crestas de Andágueda; las gargantas del Calima y del Dagua; la Serranía del Baudó con sus macizos principales, montes y voguada; del Pacífico, todo había sido visto en conjunto en sus problemas físicos, humanos y económicos.

La mayor parte de la colonización se hizo por el agua. Ríos y mares visitados en potrillos como los descritos por Colón o Francisco Silvestre, en $1789^{1}$, abrieron los secretos de la comarca. Desde 1500 hasta 1810, el curso y dirección de las corrientes, ciénagas y fajas que separan los sistemas, empezaron a figurar en informes y libros, no con la precisión requerida, pero lo suficientemente aproximada para dar a la Península una noticia de la región. El interés del oro o la fama de éste, contribuyó, como pudo, al descubrimiento de playas duras y

${ }^{1}$ Silvestre, Francisco. Descripción del Nuevo Reino de Santa Fe de Bogota. Bogotá: Imp. Nacional. 1927. 
Rogerío velásquez

boscosas, de remolinos y torrentes, de bahías y ensenadas abiertas a lagartos, tigres y serpientes.

Gracias a un funcionario español, cuyo nombre no ha sido revelado, se conocieron las posibilidades del Atrato, en 1777. En estilo ágil, vigoroso y expresivo, el Viajero Anónimo contó las vegas de la Provincia de Citará, sus ríos de estancias y canalones, sus pueblos que no crecían, los transportes del medio, las cuadrillas esclavas, los hombres de los amos, la fauna y la flora, el comercio, la vida indígena que desaparecía desde Irachura, en Andágueda, hasta la isla de los Muertos, en el mar de los caribes. Este documento con planos y mapas arroja una gran luz sobre el pasado de los hispanos en las costas occidentales de Colombia.

Antonio de la Torre Miranda Jaime Navarro, Antonio Arévalo, Antonio de Guzmán, Bernaldo de Quiroz y muchos otros, mostraron la grandeza del Atrato en sus alfaques, hoces y encañadas, ruinas y metales. Redondean estos trabajos, la investigación llevada a cabo en 1780 , por el Capitán de Ingenieros Juan Jiménez Donoso, quien por orden del Virrey Flórez puntualizó las enrevesadas bocas del gran río, sus lomas y pantanos, saltos de agua, cerros y cordilleras de madera, aves y puercos monteses, palmas reales y cimarroneras de nativos.

Otros que se encararon con el Atrato fueron Fidalgo y Montenegro. Fieles a la sabiduría de su tiempo, estudiaron sobre él la carencia de inmigración, su economía, la ninguna forma de cultura de su conglomerado, los usos y costumbres de los naturales y los emplazamientos de los negros. En sus márgenes, hablaron de las vigías de las Pulgas y Tumaradó, de Bebará y Quibdó, de los días de navegación de Cartagena a Citará, a Puerto de Andágueda e istmo de San Pablo, sin olvidarse de abogados y picapleitos que perturbaban el sueño de jueces y tenientes.

Si el descubrimiento del San Juan, en su parte media, fue obra de Melchor Velásquez Valdenebro y de su hijo del mismo nombre, en 1575, las desembocaduras fueron conocidas por Pizarra, Almagro y Andagoya. Por orden de Vasco de Mendoza y Silva, Cristóbal Quintero y Arias de Silva, recorren el río hasta Nóvita, en $1593 .{ }^{2}$ Por estos

${ }^{2}$ Ortega Ricaurte, Enrique. Historia Documental del Chocó. Bogotá: Editorial Nelly. 1921. 
capitanes entran en la historia los indios chirambiras o charambiráes, los de Baeza o Baudó, Catre y sus vecindades, las riquezas mineras de Cucurrupí y de Yarrama, los insectos que llenaban el aire, las víboras y los osos perseguidores, las tempestades siniestras que sacuden la naturaleza. Montando guardia con los arcabuces, se catean las riberas con bateas circulares, se funda a Sipí con el nombre de San Agustín de Ávila, y se cae sobre los noanamáes que irrumpían sobre Paya y Tatamá con incendios y asonadas.

Cartógrafos y geógrafos midieron y describieron los océanos, desde Morroquemado hasta Santiago, en el vecindario ecuatoriano, y desde el Cabo de la Vela hasta Veraguas. En esta labor se contaron abras y ancones, se fijaron las distancias de un punto a otro, se midieron las hondonadas y se citaron los ríos. Fieles a la historia y orgullosos de sus corraciales, los viajeros, en navíos seguros, cantaron las hazañas de los que ganaron para la monarquía tantos anegadizos y montañas, tantas barras de arena y tantas soledades.

Ojeda y Balboa, Pizarra y su gente, Cieza de León y Ovieda y Valdés, fueron los primeros en informar a España las excelencias de las costas. En 1790-1791, Alejandro Malaspina habla de la despoblación natural del Pacífico, de la pobreza comercial del lugar y la carencia de caminos. Entre estaciones opuestas, virazones y calmas, en noches inclementes y días despejados, sujetó a observaciones exactas de latitud y longitud las islas del Gallo, Las Gorgonas y Buenaventura, Chirambira y Cabo Corrientes, San Francisco Solano y los islotes de Malpelo. ${ }^{3}$

En 1810 se conocían ya los istmos buscados por Carlos V, y las casas reales de Portugal e Inglaterra. El punto de unión de los océanos que movieron los esfuerzos de Colón, Juan de Salís, Hernán Cortés, Lucas Vásquez de Ayllón, González Dávila, Gaspar de Corte-Real, Vespucio y muchos más, se descubrió subiendo el Atrato o atravesando la manigua de Napípí o Truandó. Por el San Juan y el Quito se hallaron los arrastraderos de San Pablo y los que llevan al Pacífico.

A propósito del canal de la Raspadura, el Chocó es estudiado en

${ }^{3}$ Merizalde del Carmen, Bernardo. Estudio de la Costa Colombiana del Pacífico. Bogotá: Imp. del Estado Mayor General. 1921. 
Rogerío velásquez

todas sus posibilidades. Hombres como el piloto Vizcaíno Goyeneche, en el siglo XVIII; don Antonio de Ariza, en 1774; el arzobispo-virrey, en 1789; el sabio Caldas, Humboldt y don José Ignacio de Pombo, en 1803, no sólo analizan la practicabilidad de la comunicación, sino que meten en el conocimiento de los americanos nuevas ideas de la comarca afortunada. Entre mapas hidrográficos y descripciones del ambiente, se exaltan las ventajas comerciales que obtendría el Nuevo Reino con la realización de la obra que preocupó, más tarde, la mente del Libertador.

Además de los trabajos anteriores, Humboldt se había detenido en los vegetales que alimentaban los bosques que van de Pasto a Centroamérica, para preguntarse por el número de los estudiados en obras impresas, por los descubiertos, pero no analizados, por los que llenan, en fin, el globo de las cordilleras chocoanas. Después de penetrar en el eje orográfico de la región, revisa los montes que hunden sus espuelas en el Atrato, en las costas, en el San Juan y Panamá. Frente a la conformación del territorio, se extasía en el istmo de San Pablo, en el oro de Andágueda, norte de Quibdó, Indipurdú y Nóvita, para describir los cargueros que cruzan "la humedad constante, descalzos sobre la arcilla espesa y cenagosa, y pasan a nado profundos arroyos de agua fría". ${ }^{4}$

Este era el Chocó de 1810. Ríos, lagunas y campos incultos, breñas escarpadas, páramos. En medio de centellas palpitantes, de anormalidades en la temperatura, bacterias, parásitos y virus, tierras realengas entregadas, conucos de pansembrar y recoger, escasas raíces comestibles, minas de oro y platino, etc.

Afianzado el poder político, los montes bajos podían ser cultivados por realistas convertidos en revolucionarios, por soldados o conspiradores empedernidos, o poblados por mesones y tambos de indios y barracas de esclavos. En islotes y bacanas abriría el comercio su especulación con los cerdos que faltaban o con los hatos numerosos que concedían privilegios.

\footnotetext{
4 Pérez Arbeláez, Enrique. Alejandro de Humboldt en Colombia. Bogotá: Ediciones de Empresa Colombiana de de Petróleos. Editorial Iqueima. 1959.
} 
Con la revuelta de julio, se defenderían los puertos principales. Allí estaban Urabá y Bahía Solano, Buenaventura y Tumaco, entre tantos que figuraban en las expediciones de Hernando de la Serna, Fidalgo y Montenegro. Todos eran aptos para estancias y granjerías, vigías y atalayas, cercos de vacadas y factorías de lucro. De todos partirían naves cargadas de zarzaparrilla y maderas. El honor nacional pedía luchar por estas anfractuosidades que llevarían al universo las riquezas forestales y agrarias del país.

En nombre de las ramadas largas y estrechas donde nacieron los hijos, del fuego casero que secó los petos y aljubas de los que creyeron en el dorado, los chocoanos de 1810 amaron el riesgo de las batallas y el desafío de lo sorpresivo. Por ganar el bienestar que brindaban los filones y reducir los poderes excesivos; por derribar un régimen que sojuzgaba a los hombres en lugar de servirlos; por restaurar derechos primitivos e inalienables conculcados en más de trescientos años de violencia, amos y esclavos siguieron la dirección de Santa Fe y Cartagena para romper el viejo cerco, realizar una aspiración, fundar un orden nuevo y clavar, en la conciencia de los que sobrevivirían, el sueño de nuevas esperanzas.

\section{Caminos}

La posición geográfica del Chocó influyó siempre en favor de su aislamiento. A gran distancia de Cartagena y Cali, de Santa Fe de Antioquia, Neiva y Popayán comenzó a crecer trabajosamente entre bosques tropicales, praderas y páramos, farallones, contrafuertes y pantanos, ríos violentos y de fiebres, amén de océanos difíciles para navegar en la mayor parte del año. Estas duras condiciones impedían e impiden todavía su salida natural al interior del país y a pueblos del continente.

Sin embargo, lo anterior no releva a los españoles del cargo de abandono. Tozudos y tenaces como eran, habían podido mejorar las trochas de los indios, aprovechar los baquianos de taludes y hondonadas mineras para trazar, en el corazón de la maleza, rutas de penetración, antes que conformarse con los atajos que corrían por ásperos y escabrosos senderos, peñascos elevados o valles húmedos, por laderas estrechas, derrumbas, cerros nevados, soledades, puentes qué pasar, 
Rogerío velásquez

quebradas qué seguir, ciénagas, lodos y espinas qué pisar, aguaceros continuos qué aguantar, todo a pie, de seis, diez y quince y veinte días de largo, sin otra esperanza de víveres que los que se llevan cargados en los hombros hasta llegar a los puertos y embarcaderos. ${ }^{5}$

De Bebará a Antioquia; de Bebaramá al mismo lugar; de Andágueda al Cauca; de Nóvita a Cartago; de la costa del Pacífico al Atrato; del Atrato al Sinú que llevaba a Cartagena; del Calima al Dagua, y de aquí al Valle del Cauca; de Naranjal a Sipí, y del Golfo de Urabá a Santa María, tierras de Cana y lugares adyacentes, comerciantes y esclavos cargueros tenían, fuera de boquerones, despeñaderos, fraga espesa, humedad y moho, qué pegar el cuerpo en el barro, partir las corrientes a nado o en balsas, apoyarse en plantas venenosas, troncos viejos o reptiles dormidos, descansar en madrigueras o en las raíces de los grandes árboles. Así pasaba el correo, las vituallas, los instrumentos de labranza, las semillas, telas de Quito o del Reino, paños y lienzos de altares, imágenes y pólvora.

Frente a este embotellamiento, el visitador Juan Jiménez Donoso en su Relación del Chocó, escrita en 1780, pedía, sin resultados positivos, el arreglo de los caminos de tierra que mediaban entre las provincias chocoanas y las de Popayán y Antioquia, de modo que todos pudieran ser transitados con mulas o bueyes. Los problemas del istmo de San Pablo y Bocachica; los que envolvían las montañas intermedias entre Nóvita y Cartago, y las que separan a Quibdó de Cali, obstáculos evidentes para el progreso regional, fueron llevados al gobierno de Santa Fe para ser estudiados de acuerdo con las exigencias del comercio. Los impedimentos subsistieron porque la mano de obra indígena y la de procedencia africana estaban empeñadas en servir al feudalismo ultramarino o en aporcar la aristocracia que nacía en los predios americanos.

No hay razón para que la misma comunicación de Napipí con el interior del país, conocida minuciosamente por Jiménez Donoso, no pudiera perfeccionarse. Con ella, los papeles de la Corte y los de las cancillerías del Perú, Chile, Argentina y Paraguay entrarían a Carta-

${ }^{5}$ Carrasca, Ricardo. Historia de los caminos del Nuevo Mundo. Buenos Aires: Librería y Editorial El Ateneo. 1945.

10 
gena en un lapso de treinta y cinco días, salvando el Atrato y el Sinú. La intervención de don José de Acosta en contra de la vía, produjo el milagro de dejar los montes en su sitio y las cordilleras como habían nacido, en obediencia de la fe. Otros acontecimientos se hubiesen experimentado si Felipe II deja abrir las sierras y trastornar los ríos, como lo pedía el sevillano Francisco López de Gómara, en su Historia General de las Indias.

Mientras Citará se comunicaba malamente con Antioquia y Cartagena, Nóvita salía al mundo exterior por el camino de Ita, tan traído y llevado por don Pedro Fermín de Vargas. Esta ruta comercial que nutria a Pasto, Quito y Popayán, no había crecido en limpieza ni por los esfuerzos de los capitanes Cristóbal de Troya, Pablo Durango Delgadillo, Francisco Pérez Menacho, Vicente Justiniani y Hernando de Soto Calderón. En más de ciento treinta y seis años de existencia, continuaba siendo, en 1800, "una bóveda sombría de cincuenta centímetros de ancho, cuyo suelo estaba constituido por lodazales perpetuos, y la techumbre por las entrelazadas ramas de árboles seculares, albergue de horribles ofidios y de toda clase de sabandijas". ${ }^{6}$

Otro camino abandonado fue el seguido por Balboa en el descubrimiento del Pacífico. Se le dejaría por orden de Pedrarias, por las subidas fatigantes, por la vegetación impenetrable, el calor de las hoyadas, por el miedo a las rocas cortadas a pico o a las serpientes que se ensañaban contra hombres y caballos. Se le descuidaría probablemente por los mosquitos y jejenes, por sus alturas y espejismos que mareaban, por los murciélagos que desangraban, por los puentes de bejucos levantados por la indiada. Con el olvido de esta vía se detuvo el avance cultural del bajo Atrato, la comunicación con Antioquia y la Provincia de Biruquete que correspondía en mucha parte al territorio chocoano.

El sendero que comunicaba a Cali con los ríos: Timba y Yurumanguí, "de piso firme y sin ríos, propio para el tránsito de bestias", como escribió de él don Pedro Agustín de Valencia, tesorero de la Real Casa de Moneda de Popayán, fue olvidado como el del Dagua a Vijes, por donde había pasado Andagoya y bajado gente de Benalcázar. Con la pérdida de ambos se cancelaron las posibilidades de colonizar el Alto

${ }^{6}$ Merizalde del Carmen, Bernardo. Op. cit. 
Rogerio velásquez

y Bajo Chocó, en las desembocaduras de sus ríos principales ricos en oro, esclavistas y africanos, como pobres en cultura y educación, economía y disciplinas manuales y en arrestos para vencer el lodo de los caseríos, las emanaciones de los manglares, las enfermedades y el hambre que se calmaba con raíces, plátano, ratas salvajes y pescado.

De los ríos se acordaron en España para cerrar los como ocurrió con el Atrato, para cobrar por cruzarlos, o por los quintos que producían sus arenas. Escollos, agua que se estrella en las rocas, troncos de árboles, precipicios, orillas montuosas, fragosidades imposibles de remediar en los terrenos cercanos a sus márgenes, cosas adversas que ayudaron a afirmar la libertad de la persona humana, sólo fueron vistas en los albores de la revolución por don Antonio Villavicencio, trescientos años después que los nativos habían luchado con ellas con el cuerpo y el alma, con la sangre y los huesos, los pulmones y la vida.

La comunicación marina se vio interferida por requisitos y disposiciones. Condiciones físicas de las embarcaciones; permisos sanitarios, visas y órdenes de Quito o Perú, Panamá, o Santa Fe, eran necesarios para viajar de Chirambira a Guayaquil, Lima o Callao. Con estas restricciones, sólo se podían efectuar dos o tres salidas al año, "gravando a los interesados en alguna cantidad, con la estipulación de no navegar otro, para que escaseando los víveres y efectos se vendieran a los mineros; por el dueño del barco, como único vendedor, a más, subido precio".?

La costa sur esperaba anualmente una nave con el comercio que cruzaba el Cabo de Hornos. Con más viajes y menos lucro de los dueños de canoas chatas y champanes, el bajo Chocó habría conocido talleres, agricultura, comercio, contacto político con el mundo de Santa Fe o Panamá, ciudades y escuelas; con navegación regular, el océano que vio Balboa desde las cumbres del Quarequá, gobernó Andagoya hasta San Juan de Micay, y metió en la historia universal don Francisco Pizarra con sus luchas y mortificaciones, habría enseñado a sus hombres a vestirse, a disminuir los ídolos y los adoratorios del demonio, a formar y templar el carácter para sortear con éxito la miseria que los aquejaba.

\footnotetext{
${ }^{7}$ Giraldo Jaramillo, Gabriel. Relaciones de Mando de los Virreyes de la Nueva Granada. Bogotá: Publicaciones del Banco de la República. Imp. del Banco de la República. 1954.

12
} 
Al estado español no lo preocupaban las ventajas militares ni las responsabilidades de la colonización. Bases estratégicas, defensa de fronteras, ruedas y caballos se olvidaron en esta parte del Nuevo Mundo. Para la capa social dirigente, lo interesante eran sus posibilidades de subsistencia, el oro para halagar, lisonjear y merecer, propiedades para transferir, esclavos para lograr o donar, indios para oprimir, reales mineros para gozar con avaricia. Para abatir estos excesos, los de abajo, conociendo sus raíces, se abrazaron a la revolución granadina comenzada por el padre Las Casas en la primera mitad del siglo XVI.

\section{Parte primera \\ Las razones de la independencia}

"Cuando una larga cadena de abusos, y usurpaciones, que persiguen in variable mente el mismo objetivo, hace patente la intención de reducir al pueblo a un despotismo absoluto, es derecho del hombre, es su obligación, arrojar a ese gobierno y, procurarse nuevos guardianes para seguridad futura."

(Preámbulo de la declaración de Independencia de los Estados Unidos de América).

\section{- I- \\ La provincia económica}

\section{a) La agricultura regional}

Si la agricultura del Chocó en los tiempos actuales, es algo desastroso, la de la Colonia fue apenas de subsistencia. Diez mil ríos, treinta o cuarenta grados centígrados de calor, humedad relativa de $85 \%$, nubes amontonadas y electricidad atmosférica que se resuelve en relámpagos, rayos y centellas, y precipitación pluviométrica de 8 a 10.000 milímetros, tenían que incidir sobre la agricultura. Como consecuencia, aparecieron el hambre, la pobreza económica y los malestares generales que criaron las tensiones internas entre las clases regionales.

No obstante los signos anotados, la tierra, obedeciendo la política de los reyes, habrían podido mejorar los niveles de vida de los habitantes. Lavado el suelo por la lluviosidad, quedaban las terrazas alu- 
Rogerío velásquez

viales de las riberas, las localidades costeras del Cario donde estaban ubicadas Concepción, Mandinga y Caimán, y las veras de los ríos que desembocan al Pacífico. Frente a estas condiciones, amparadas por la hidrografía y la climatología ambientales, se alzaba el español mortificado por las inundaciones y vientos que desgajaban las colinas, las hoyadas coluviales sin vías, la mano de obra escasa que se debía pagar, la selva cercana con sus hormigas y pulgones que empobrecían los cultivos, el contacto con animales de presa, especialmente el murciélago que desangraba el ganado.

Fundas o granjas en un suelo como el nuestro requerían voluntad, poderío, ansias de producir como Antioquia, Valle o Cartagena. Mas el peninsular fue inferior al medio que lo sostenía. De ahí el precario sustento con que se alimentaba, la dispersión de sus centros poblados, sus fallas de previsión, su inestabilidad y desamor al agro, su torpeza en transportes y en problemas sanitarios. Con buques, caminos y mercados, había acelerado el crecimiento de las aldeas, explotado con éxito los recursos naturales cambiado las costumbres de los colonos y campesinos, dado vigor, a la economía general que se asentaba, antes que todo, en la armazón de los minerales.

El terrateniente pastuso o payanés no fue hombre de planes para el porvenir. En medio de tempestades agresivas como las descritas por Caldas, se contrató con un monocultivo frugal, pobre y desmirriado. Chontaduro, yuca, plátano, ñame, granos de maíz, dos o tres árboles frutales, caña dulce y cacao en pequeñas cantidades. Para él, la libertad política se conseguía con el ejercicio de socavones u hoyaderos, tomas o fosos longitudinales. Empero, disputaba por tierras vecinales que se destinaban para la descendencia, nunca para labrarlas y convertirlas en recursos alimenticios de que tanto se necesitaba.

Hablando de lo agrícola, el Chocó era rico como el que más del Nuevo Reino. Los inconvenientes de su geografía contribuían a ello. Agua por todas partes. Tierra abundante para una fragmentación proporcional y adecuada de la población, y clima variado, todo hablaba de sus posibilidades potenciales.

La fertilidad del país, que además de dar con abundancia todos los frutos necesarios para la vida, puede enriquecer a sus, habitantes con 
sus preciosos productos de oro en muchas minas, cacao, añil, tabaco, café, algodón, cañas dulces para azúcar, palo de tinta y carey, además de cera de indio y todo género de maderas y materiales. Pues si en las mejores colonias que tienen los extranjeros en estos dominios, algunos de estos frutos, que se dan separados de ellas, las hacen ricas y de tanto aprecio, y a la isla de Cuba el azúcar y el tabaco, ¿qué utilidades no se podrán sacar de esta provincia donde se hallan juntos todos estos productos, con la facilidad que dan tantos ríos para cultivarlos y conducirlos? Bien puede creerse que fomentándola podrá hacerse en poco tiempo una de las mejore de la América, y que más rinda a nuestro Soberano. ${ }^{8}$

Pero el español que estaba de paso en matorrales y sabanas, no logró ver ni adivinar estas ventajas. Trastornado por el regreso a la tierra de origen, rico y poderoso, no se detuvo en los campos de cultivo de doña Clemencia de Caicedo, en los predios de Leonardo de Córdoba, en los bosques de Unguía y de San Joaquín de Nauritá, en los paisajes naturales de Bojayá, Munguidó y Tamaná, en las vertientes templadas del San Juan o el Atrato. Al pueblo conquistador le bastaba buscar oro, vivir como refugiado, ahorrar equipo, comer mal alojarse en peores condiciones. En su presupueste no figuraban comunidades felices, prósperas y uniformes que sintieran el deseo de vivir plena y cabalmente.

Puesto que los vencedores adoptan los vicios costumbres de los vencidos, el blanco del Chocó se alimentó de plátano, allí así, raíces y trozos de chontaduro que se encontraban en todas partes. Sin rotación de cultivos, no podía hacer más. La escasez de ganado se suplió con carnes de guagua, saíno, tatabros, venados, peces salados y lonjas salpresas de guayaquil, Cartago o Cartagena. Con razón decía Jiménez Donoso "que unos mantenimientos y caldos, que son los renglones más fuertes, son demasiadamente caros, por lo que todos parecen confundidos y envueltos en su oro y su miseria, a excepción de alguna docena de mineros que a fuerza de industria, trabajo y fortuna, se les conoce algún caudal". 9

\footnotetext{
${ }^{8}$ Contraloría General de la República. Geografía Económica de Colombia-Chocó. Bogotá Imp. Nacional.1943.

${ }^{9}$ Ortega Ricaurte, Enrique. Op. cit.
} 
Rogerio velásquez

Aunque las tierras de pan sembrar, estancias de ganado mayor o de caballería habían sido donadas para el sostén de los esclavos, la avaricia ultramarina, apoyándose en la Cédula Real del 15 de octubre de 1754, llevó los baldíos a propiedad privada de los dueños de los entables. Con esta disposición el San Juan se dividió, entre veinticuatro mineros de Popayán, Santa Fe y algunos señores del lugar, y el Atrato se parceló entre quince terratenientes. En ninguna de estas divisiones se metieron semillas y pienso, trapiches, huertas y ganado. Antes que plantaciones, los fundos se convirtieron en rancheríos donde vivía el minero y su familia, al lado de centenares de esclavos que componían estanques, bajaban a los zambullideros o morían bajo el peso de los derrumbes que aplastaban contra el cauce de los canalones.

A falta de explotación agrícola de las nuevas tierras recibidas, las oligarquías caucanas cobraron impuestos por usarlas. Plantaciones y sementeras, corte de maderas, caza y pesca, fueron tasados. Además de prisiones por deudas, insultos y vilipendios, el colono negro o el mulato, se vieron obligados a hacer agricultura nómada y difícil por la situación de los transportes, por la falta de un gremio interesado en los cultivos y por las minas que permitían el incremento ilícito del oro que se "registraba en la Aduana, sin pasar una vez siquiera manos de los labradores". ${ }^{10}$

Mulatos, zambos y negros libres cultivaban para sobrevivir. Don Carlos de Ciaurriz, que los vio personalmente en 1803, dice de ellos: "La situación baja, pantanosa y anegadiza de lo interior de estas montañas no tiene otro recurso que el de las vegas que hay distantes unas de otras en la longitud de los ríos. En ellas residen precisamente dispersos mulatos, zambos y negros libres de dichos partidos para cultivar y subsistir con sus familias, alimentándose con los mencionados frutos y la miel que benefician de la caña y haciendo comercio proporcionado a sus cosechas con los mineros y los pueblos y con la gente de otros ríos". ${ }^{11}$ El maíz se comerciaba con los naturales, que lo vendían a dos tomines el almud.

Ya está dicho que el indio trabajaba para los corregidores. De enero

${ }^{10}$ Giraldo Jaramillo, Gabriel. Op. cit.

${ }^{11}$ Ortega Ricaurte, Enrique. Op. cit. 
a mayo y de agosto al 15 de octubre, permanecía ocupado, con sus propias herramientas, en sembrar para los recaudadores. Los jornales de cuatro reales diarios se recibían

(...) en machetes, hachas, cuchillos, cascabeles, chaquiras, trompas, peines, bayeta de Quito, mantas, lienzos y frazadas del Reino, sortijas de cobre, orejeras de estaño, manillas o brazaletes de plata y otras menudencias de lo mismo para gargantillas y todo a precios muy subidos, de modo que el miserable indio sólo viene a ganar una tenue cantidad recibiéndola en las especies que quiere el corregidor y no en las que necesita. ${ }^{12}$

Para evitar la rebelión contra semejante tratamiento aparecían el cepo, la fuerza del látigo, los cambios de localidad, las retenciones en los pueblos.

En la cercanía de piratas, el cuna entraba en la faena agrícola con alma desesperada. Lo movía la venganza y, en ocasiones, el vestido. Cacao y algodón de Urabá, mieles, lanas y resinas de Tumaradó, brea y raicillas de Tarena, se cambiaban por escopetas, pólvora, balas, armas blancas y licores. Ingleses, holandeses y franceses de las colonias de Jamaica y Curazao enseñaban a manejar armas de fuego para defender once ríos y quebradas, habitaciones y estancias, cinco pueblos y sus tradiciones tribales que mermaban corsarios, negros cimarrones y españoles americanos.

Las barreras aduaneras creadas para contener el comercio no español, obligó a los militares y aventureros que usufructuaban la región, a comer pan a cuatro reales la libra; sal en grano del Ecuador a catorce y veinte castellanos de oro, el tercio de cinco arrobas; carne salada de res, por dieciséis, veinticuatro y treinta castellanos, las cien libras; arrobas de azúcar transportada por Andágueda y el Golfo de Urabá, por dieciséis hasta treinta y seis castellanos, cada una; harina extranjera, de dieciséis a veinticuatro castellanos; una botija de vino del Perú, por veinticuatro castellanos. Los productos de la tierra como aguardiente, cacao, carne de cerdo, gallinas, se reemplazaban por anisado de contrabando, carne de monos y puercos monteses, pavas y paujíes, y pescado salpreso o fresco cazado con arpones, lanzas y atarrayas.

\footnotetext{
${ }^{12}$ Ortega Ricaurte, Enrique. Op. cit.
} 
Rogerio velásquez

Ya en las postrimerías de la Colonia el comercie fue libre y casi todo realizado por contrabandistas, Sin el correspondiente pago de los quintos, salían por el Atrato el oro, la quina y los frutos a Portobelo en espera de los convoyes. Esta fuga de la riqueza nacional por "una costa dilatada y despoblada, con abundantes surgieras", como lo anotó el virrey Mendinueta en 1803, dio poder a los corsarios que se agazapaban en los puertos del Sinú y Urabá, disminuyó el numerario regional, produjo carestía de géneros, efectos y mantenimientos que venían de Europa, y ahondó la pugna entre comerciantes españoles y criollos, lo que contribuyó a debilitar más los vínculos de la camarilla que consideraba el trabajo como un oprobio que debían soportar por su desgracia, los de abajo, en beneficio de los potentados.

\section{b) Minería}

El ideal de los colonizadores de "recoger bastante oro, bastante platino, y recogerlos aprisa; y entre tanto, sobre una barbacoa, y entre el fango y la maleza, como los cerdos y con ellos; alimentarse con plátano que brindan los campos y con pescado que ofrecen los ríos, regalándose en los días grandes con un palmo de tasajo conducido desde el Cauca; andar casi desnudos, el pie en el suelo, con una camisa de listado y unos altos y estrechos pantalones de dril; zambullirse, buzos codiciosos en aquel mar de calor, de humedad, de miasmas y de plagas, con riesgo de la vida y pérdida de la salud, por amontonar a todo trance: toda carrera, con el trabajo del esclavo, fuertes riquezas, para ir luego a disfrutarlas a otras partes, ${ }^{13}$ se desvaneció, para muchos, por las siguientes razones:

a) Métodos de trabajo - Los elementos dedicados a la minería eran escasos y anticuados. La pobreza técnica radicaba en el hecho de que entre los españoles apenas había mineros de oficio. Las herramientas que venían de España, y el crecido precio del hierro en la Península, obligaban a trabajar en forma rudimentaria, separando con las manos las arenas para extraer de su seno las pepas de oro que se buscaban afanosas.

${ }^{13}$ Espinosa, Mario. "Viaje al Chocó”. Bogotá: Publicación del periódico Comandos. 1944. 
Para abrir una mina se usaban macanas o coas, además de barras de hierro que labraban los esclavos. En todo montaje había un forjador de barretones y almocafres que ayudaban a remover el lodo de los canalones. Con la forja catalana, los negros ablandaban el metal y preparaban los instrumentos.

De azuelas, barras y barretas habla Las Casas; como elementos usados por los indios en cata, o cateas de oro en pozos y tiros verticales. Más tarde se agregó la batea o artesa circular fabricada a compás, ojo y machete. Grandes o medianas, servían para pruebas en cerros y ríos, bombear agua de las profundidades, lavar menas, transportar menesteres caseros, etc. Las bateas fueron de mucha utilidad en esa época en que la minería se hacía sin estudios, sin conocimiento de geología ni de geometría subterránea.

El mazamorreo se diversificaba, en ocasiones. Aquí, era la toma que represaba el agua de las quebradas en forma de escalones hasta llegar a las arenas auríferas; ahí, el canalón que exigía un número considerable de obreros armados de manos, uñas, cachos y barretas; allá, el socavón de regular profundidad y longitud, de incierto encuentro con la veta minera; más allá, el hoyadero, dado en los terrenos reconocidamente pobres. Para complementar el sistema, aparecía el zambullidero que se cumplía por jóvenes más o menos robustos, que se hundían en los torrentes con el espinazo encorvado por la pesada piedra que descansaba en la espalda, llevando contenida la respiración que, si ampliaba el tórax, rompía los pulmones y oídos de los infelices africanos.

De esta forma, el progreso económico era lento. Sin molinos como los proyectados por el Conde de Casa-Jijón; sin máquinas para tajar vetas ni cuerpos mineros organizados como en México; sin un fondo anual para apoyar la obra de los trabajadores pobres; sin que nadie tuviese conocimiento de mineralogía, ciencia pedida por Pedro Fermín de Vargas, en algunos de sus estudios; secando lagunas con zanjas a impulso de bateas; cambiando el curso de los ríos con madera y arena para alcanzar el mineral; transportando materiales a hombro para tender los canalones en zig-zag; sin agua permanente para correr la arena de los entables; sin dinero para construir pilas o estanques; sin 
Rogerío velásquez

molinos, de pisones y de arrastre como los empleados por Boussingault, en Mariquita; sin cuñas ni almádenas; sin conocer el uso de la pólvora para volar rocas y peñas, ni grúas para remover los obstáculos, la minería chocoana, en la época colonia, no fue una ventaja sino un sacrificio.

b) Pobreza de los mineros -Con lo anterior, el negocio empobrecía. Don Pedro Fermín de Vargas, que estudió a fondo el problema, escribió:

Por cálculos bien aproximados se ha computado que entre minas ricas, medianas y pobres, unas con otras, sacará el negro más diestro la sexta parte de una onza de oro, o dos pesos cinco reales, excepto el real del día. El año lo dividen los trabajos por mitad, empleando la una en la extracción y caza de las arenas auríferas, y la otra en su lavado. Quitando noventa días de los trescientos sesenta y cinco del año, por razón de las fiestas, quedan útiles doscientos ochenta y cinco, de los cuales se emplea la mitad en lavar las arenas menudísimas, que producen por cada negro 374 pesos y medio real.

Como los víveres son extremadamente escasos y caros en las tierras de minas, por razón de ellos, vestuario y enfermedades, que gaste diariamente un negro cuatro reales, quedando en favor del amo 191 pesos, cuatro y medio reales anualmente. Quitemos por razón de herramientas, gastos de bateas y otras menudencias de poca consideración, 8 pesos todos los años al respecto de cada negro, y quedan 183 pesos, cuatro reales y medio, poco más de 90 pesos de oro. Rebajando de este producto los derechos de quinto, fundición, amonedación, etc., apenas quedan a favor del minero 80 pesos de oro o 160 de plata. De manera que suponiendo que un minero mantenga su mina corriente con 50 negros, gana todos los años 8.000 pesos, pero muy pocas son las minas de estas conveniencias". ${ }^{14}$

Hasta 1803, según Carlos Ciaurriz, "las minas del Choco se lavaban cada seis meses, con cuadrillas y mayordomos o administradores, capitanes o capitanejos. Separado el oro de la platina, y apuntadas las

14 Vargas, Pedro Fermín de, Pensamientos políticos y memorias sobre la población del Nuevo Reino de Granada. Bogotá: Biblioteca popular de Cultura Colombiana, Imp. Nacional. 1944. 
cantidades en los libros respectivos, se denunciaban a las Cajas Reales para satisfacer el Real derecho de quintos a razón de 3\%". ${ }^{15}$ Lo sacado, extraídos los doblones de su Majestad, no alcanzaba para cancelar los costos; pagar los comestibles y demás cosas necesarias para la vida humana.

De esta forma el empeño de los mineros, sus pleitos continuos y el pago de sus deudas con los negros, desmantelando la provincia, hacían la pobreza general, lo que se hubiese evitado explotando la sal del Atrato o el cobre de Andágueda o la plata de los criaderos del San Juan, para citar minerales que pesaban en Europa. Pero el español puro o el raizal americano se deslumbraban con el oro que sostenía navíos en Génova y Cerdeña, Sicilia y Nápoles, amén de fuertes y atalayas organizados meticulosamente para la defensa de los turcos en las costas italianas.

Tiempos de calamidades mineras fueron los años de 1756, $1777 \mathrm{y}$ 1780, por el alza del fierro, el acero y el sebo colados. Para el último año citado, la región pedía artesanos calificados como los de Cartagena y Portobelo, y sobre todo, productos extranjeros que supliesen los que la metrópoli no podía proporcionar a bajo precio como vestidos, alimentos, herramientas e instrumentos de la capital. La ruina fue tanta, que los entables de don Ignacio de Rentería, Franco Martínez y Leonardo de Córdoba, se vieron tan afectados que, de cuadrillas crecidas como eran, bajaron, en 1796, a ser simples lavaderos, donde la gente principal se dedicaba personalmente a buscar el metal que necesitaba para no perecer de hambre o tener que entregar, por deudas, a los comerciantes de fula, cerdos, bayeta y otros trapos, los escasos esclavos que les quedaban dispersos y desordenados.

Estos mineros insolventes fueron un acicate de la revolución. El hacer trabajar la chusma de sol a sol; el esperar sin inquietudes el producido de los canalones; el hacer ningún caso de las disposiciones oficiales, en especial de la Cédula Real del 31 de mayo de 1789 que miraba por la utilidad de los siervos, y trataba de atenderlos en la educación, alimento, vestido, ocupación, diversiones, habitación, enfermedades, penas y castigos, produjo escándalo en los rancheríos y

${ }^{15}$ Ciaurriz, Carlos. Archivo Nacional. Salón de la Colonia. 
Rogerío velásquez

sediciones en los canalones. Los excesos ocurridos en Sesego en 1800, prueba lo que decimos.

La minería, dividió a los colonos en pobres y ricos, es decir, en amigos del sistema gubernamental imperante y en enemigos del mismo. Los primeros no deseaban permanecer sometidos a hijos o nietos de conquistadores o americanos, por no pagar tributos ni derechos delegados o subdelegados, correr las contingencias de exhibición de títulos, ni entenderse con problemas de composición de tierras, o esperar la tardía confirmación real de la propiedad, en tanto, que quedaba con la obligación de fomentar la población y de aumentar, mediante cultivos, la chacra miserable. Los ricos, empero, se acercaban al gobierno por las ventajas que recibían abusando de las leyes.

Zambos, negros y mulatos libres, por su exigua capacidad tributaria, crearon la minería nómada. Sin trapiches ni cacao qué cuidar; sin tierras qué deslindar o amojonar; sin expendios de granos qué distribuir entre los dos o tres esclavos que mantenían, se fueron juntando con otras gentes de color o con mineros extraños a la región, aunque pobres como ellos. Como la tierra era sana se podía salir a poblar ríos y madrigueras desconocidos, donde se pudiera maquina contra la Corona, contra alcaldes que ganaban sueldos, contra vecinos de calidad que mantenían esclavos, contra la vida azarosa. A estos hombres de carnes y hueso se debió, de 1810 en adelante, el sostenimiento de la resistencia, y en cierta manera, el éxito final de la empresa libertadora.

\section{C) Los pueblos}

En la fundación de una ciudad española en América, se tenían en cuenta diversas circunstancias. Situación, emplazamiento, condiciones físicas, previsión de ensanches, armonización de barriadas de indios y españoles. Sanidad, tráfico y servicios públicos, todo se estudiaba meticulosamente a fin de cumplir con las ordenanzas recogidas en la Recopilación de leyes de Indias, que ordenaban a las fundaciones "tener comodidad de agua, tierras y montes, entradas y salidas, y labranzas y un exido de una legua de largo donde los indios puedan tener sus ganados".

Estas disposiciones no se cumplieron en territorio chocoano. Bus- 
cando las riquezas de los metales preciosos, los poblados se hicieron en las quebradas de oro corrido en las vertientes con playas donde se pudiera mazamorrear, en los palenques o represas que horadaban los cauces o riberas. Quedaron sin estudiar el clima, el suelo, el relieve y las zonas de cultivo, es decir, los puntos claves que explican las relaciones primarias entre al campo y la ciudad. Por olvidar estos pormenores, Citará aparece en la derecha margen del Atrato, sobre un banco de cobre, Tadó, en una isla de escasas proporciones, y Riosucio en territorio inundable.

Todos los pueblos - decía un viajero- están situados en las vegas de los ríos, que unas más altas, y otras menos, son de reducida extensión; y aunque es mayor la que tienen algunas por la parte de sus declives, que descienden a lo más bajo de sus terrenos, es inútil para edificar respecto de ser perennes los manantiales y ciénagas que allí se encierran. Por eso están ceñidas las poblaciones a los recintos de dichas vegas, cuyas situaciones desiguales y barrialosas por su poca firmeza, y la lluviosa constitución del clima, se remedian terraplenando lo posible con la piedra menuda y el cascajo que brindan los ríos en el verano, como también poniendo puentes en las zanjas y los arroyos que circundan las poblaciones. ${ }^{16}$

Consecuencialmente, geografía y estructura habitacional, colindaron. Aquí, pobreza y mugre en los ranchos de vara en tierra de los caños mineros; ahí, tambos indígenas, abiertos al sol y a la lluvia, erguidos sobre pilotes; allá, cubiertas de paja de cuatro planos pendientes, dentro de las cuales se realizaban todas las funciones. En Atrato o San Juan, en Urabá o la costa del Pacífico, la vivienda fue abrigo rudimentario y provisional contra el clima, la selva, las avenidas de los ríos y el paso de las serpientes. Habitaciones de esta índole indicaron la tendencia trashumante de la población, en marcha tras del oro que saltaba de una ribera a otra, de una a otra provincia, de las minas de Guapi a los socavones de Cana o Quiebralomo, de las planadas de San Pablo Adeptro a los zambullideros del Calima.

Los colonizadores no sintieron el ambiente templado del Tamaná o de Sipí, las abras ardientes de Sapzurro o Acandí, las faldas de las cor-

\footnotetext{
${ }^{16}$ Ciaurriz, Carlos. Archivo Nacional. Salón de la Colonia.
} 
Rogerio velásquez

dilleras que enmurallaban la tierra. Las reservas del Baudó, las islas de Malpelo o las Gorgonas, eran campos de trabajo propicios a catedrales y monasterios, a establecimientos educativos y siembras de toda clase, a pastoreo de ganado, a lanas y cordajes. Sin embargo, la monumentalidad a que era aficionado el español, no llegó a desarrollarse en estos lugares por temor a herejes o por asaltos de indios, por la inconstancia de los pobladores o por golillas regionales que creían ciegamente en la eficacia del papel sellado.

Para luchar contra las importaciones clandestinas urgían ciudades en los caminos solitarios, en las vegas de los ríos, en los talones quebrados de los cerros. Para defender los correos de Panamá, de Chile a Cartagena, pasando por el istmo de Naipí o Napipí, se requería cortar los riscos con aldeas, partir la lejanía con casas y hombres. La complacencia con el paisaje, y la pereza de los capataces para romper los farallones con la mancha de los territorios en caso de guerra. Las depredaciones de franceses y portugueses en los caminos de Antioquia y bajo Atrato, fueron posible por el despoblamiento.

Tierras para resistir el empuje de piratas ingleses y bucaneros de Jamaica, las había en Cacarica, Pacurundó y en los altozano s de Las Pulgas, en el cañón del río Atrato. En Nóvita, sobraban los arrastraderos de San Pablo, Juntas del Tamaná, y San Joaquín, pasos obligados de los que penetraban en nuestra comarca. Con la inversión de parte de los 300.000 castellanos de oro que se producían en la comarca cada seis meses, se habrían levantado fortalezas como las pedidas por Jiménez Donoso en 1780, tras de las cuales el indio indefinido y el esclavo, habrían defendido el comercio de los atropellos de tantos que, viviendo en holganza; amancebamientos y bebidas, interceptaban los correos, quemaban la correspondencia real o de los particulares, y se incautaban los intereses del Virreinato o de los adinerados de las minas.

Desaparecido San Andrés y muerta Santa María del Darién; aniquilada San Sebastián de Buenavista y sin valor económico Mandinga y Concepción, el mar Caribe servía para hundir naves que iban a la Española por géneros o a Sanlúcar de Barrameda con intrigas y apetitos. Las olas encrespadas no hacían daño a puertos abrigados como Cartagena o Santa Marta, sino a Zapote, aldea de negros refugiados 
de todos los puntos del golfo de Urabá, boquete selvático que se alimentaba con "el canto fúnebre de los monos, el desagradable silbido del alcatraz, el monótono caer de los aguaceros sobre las ramas de los árboles, el zumbido de los insectos, el estridente grito de los rayos y el sordo retumbar de los truenos", como escribió en su Diario don Joaquín Acosta, en 1820.

En el Pacífico nada valían ni Puerto Quemado, ni San Francisco Solano, ni San Juan de Micay, Barbacoas ni Tumaco. Buenaventura, era "tierra inhabitable, calidísima y encerrada por una espesa selva que no permitía el paso de caballos", ${ }^{17}$ e Iscuandé se presentaba "paupérrima y de pésimos vecinos" ${ }^{18}$ según dijo de ellas fray Jerónimo Escobar, en 1582. En todas ellas la marea cortaba el avance de los buques para dar paso al hambre, a la escasez de sal y telas baratas para la Plebe de los minerales, hierro para los barretones, y almocafres y perendengues para los naturales.

Como Toro, sobre el Tamaná, "con veinticuatro españoles, indignos de tener vasallos a quien enseñar la fe eran Lloró, Beté, Cajón, Monte Carmelo; Bebará o Bagadó. El conformismo de los habitantes no dejaba salvar los arroyos con puentes, desecar, rellenar. Hacer estos trabajos implicaba arraigarse en el tremedal que crecía en la tierra y el agua, atrás de los barrancos y en los valles de estancias. Para el colonizador del Chocó, el trópico fue una empresa comercial que era necesario explotar con sus hombres y sus circunstancias en beneficio de Europa.

"Los pueblos de más agradable aspecto, de más número de vecinos distinguidos y de comercio más floreciente, son, inclusive la capital de Nóvita, los de Tadó y Sipí, de aquella provincia, y el de Quibdó, de la de Citará". ${ }^{19}$ Sin embargo, el virrey Caballero y Góngora, al fijarse en las ciudades del Virreinato, escribe:

A excepción de las pocas ciudades de primer orden; que tal grado merecen respecto de las del segundo, de mera apariencia en sus infelices edificios, de las del tercero, por la memoria de sus ruinas y vestigios; a excepción de algunas parroquias que posteriormente se

\footnotetext{
${ }^{17}$ Archivo Nacional. Salón de la Colonia.

18 Archivo Nacional. Salón de la Colonia.

${ }^{19}$ Ciaurriz, Carlos, Archivo Nacional. Salón de la Colonia.
} 
Rogerío velásquez

han fundado bajo mejores auspicios, todas las demás poblaciones del Virreinato son un reducido y pequeño conjunto de miserables ranchos, chozas y bujíos. . . ${ }^{20}$

Así eran los poblados del Chocó, al final del siglo XIX. Entregados por el virrey de Santa Fe a los corregidores, se convirtieron en ladroneras de compañías sueltas que formaban el ejército, en barbacoas de escándalo, robo y cautiverio de clases infelices económicamente. En su seno, tenientes y mandones vendían indios o los repartían, cazaban negros con perros para devolverlos a los amos, o montaban patíbulos a la derecha, a la izquierda, apoyados en Aristóteles y en citas sueltas del Antiguo Testamento.

\section{d) Los impuestos}

La tierra "húmeda, pluviosa y desgraciada", que recordó don Juan de Castellanos en una de sus Elegías, fue, desde el aparecimiento de Santa María la Antigua del Darién, campo de explotación y rebatiña. Conquistadores, corregidores, tenientes de gobernadores y jueces, gentes de exploración y montoneras de soldados, usaron y abusaron de la fuerza del poder para sacar, de siervos sin pan y de la gleba sin nombre, tributos que no llegaban a España por la fragosidad del territorio a la codicia de los recaudadores.

Indios de planadas o arroyos, de laberintos o de valles, todos fueron gravados. Para sostener el idilio político de los europeos y la anchurosidad de la evangelización, los de Quibdó fueron tasados con tres pesos, con dos los de Anserma y Noanamá, aunque obligados a proveer de maíz los minerales, y trabajar seis meses para los corregidores. La costumbre de tales Contribuciones, que caló tanto en el interior del Nuevo Reino, dio margen, sin embargo, a que Alonso de Hincapié, procurador de Toro, enjuiciase a Melchor Velásquez, el fundador de la ciudad, y a mover la rebeldía de los urabáes, tatamas, chancos y coronados, payas y raposos hasta la entrada de 1800 . Hombres de behetrías, carecían de hábito para dar regalías exorbitantes a reyezuelos comarcanos.

\footnotetext{
${ }^{20}$ Morales Benítez, Otto. Muchedumbres y Banderas. Bogotá: Publicaciones Tercer Mundo. 1962. 
Los dos y medio patacones anuales que se cubrían por los tercios de San Juan y Navidad; los seis patacones impuestos a los chocóes en 1751, lo mismo que a los anaconas y forasteros de la ciudad de Popayán, Buga, Cali, Caloto, en tanto que a los iscuandées, barbacoas y raposos, se gravaban con ocho, ${ }^{21}$ el contribuir al sostenimiento de la curia con primicias y obenciones que se extendían a los tenedores de esclavos, provocaron discusiones entre gobernadores vecinos como los de Antioquia y Citará, y fugas en masa de naturales, en Lloró, Domingodó y Chintadó, Caimán y Bojayá, en el Atrato.

Por tantas cargas desaparecieron Santa María, en el Golfo de Urabá, Lloró, Buenaventura y los emplazamientos civilizadores de los agustinos descalzos, en el Darién panameño. Si ello fue así, no es del todo exacta la afirmación del señor Groot, cuando escribe: "Después de la revolución de 1810, los indios se presentaban porfiadamente ante los corregidores con el empeño de pagar el tributo de su amo el Rey, y muchos de ellos lloraban cuando se les decía que ya no había Rey a quien pagar tributo". ${ }^{22}$ Estos indios no debieron ser los pijaos que destruyeron a Neiva y a la Plata, ni los chibchas del Tamaná, en el hoy municipio de Nóvita, que arrasaron para siempre la naciente Sed de Cristo, levantada por los jesuítas.

No se escaparon los negros de esta fiebre de tributos. Nada importaba que viviesen al borde de lagunas palúdicas y entre vapores enfermizos. El mazamorrear en los ríos que había ayudado a descubrir y a poblar, imponía un gravamen de un castellano de oro por persona, lo mismo que por comer carne de manatí, tratar con amos blancos, usar montes y maderas, cazar y pescar. A la empresa de la expansión de la fe y de las ciudades de otros puntos del continente, al cabotaje y al extrañamiento de piratas, debía contribuir con su óbolo, así hubiese llegado en cadenas y en buques hediondos o careciese de un palmo de tierra de los que daban los reyes a quienes le servían al imperio.

El derecho de mazamorreo, aunque lo pagaba tila clase más miserable de los chocoanos, para emplear una expresión de don Juan de Aguirre, último gobernador de España en nuestra comarca, era para

\footnotetext{
${ }^{21}$ Ortega Ricaurte, Enrique. Op. cit.

${ }^{22}$ Groot, José Manuel. Historia Eclesiástica y Civil de la Nueva Granada. Bogotá: Casa Editorial de M. Rivas y Cía..1890.
} 
Rogerío velásquez

libertas, blancos y mulatos y gentes libradas de cuadrillas, o sean aquellos infelices que acabando de salir de la esclavitud continuaban el ejercicio de extraer el oro y no alcanzaban a tener cinco esclavos para llamarlos mineros. ${ }^{23}$ En el quinquenio de 1805 a 1809 los de barrancos, rancheríos y congostos, trabajando con las uñas, produjeron 3.684 pesos que servirían para sostener las milicias que intimidaban a los negros y contenían a los indios en sus movimientos defensivos.

Los quintos y cabos de 1754, montaron a 1.315 castellanos y ocho granos de oro, sin contar 733 castellanos y nueve granos de tributo. Las ramas de papel sellado, alcabala de cuatro por ciento, aguardiente, media anata y tierras, produjeron en el año citado, 2.366 castellanos, once y tres cuartos de granos que fueron avaluados en 8.826 de oro, o sean 17.656 patacones. En 1778 y 1779 se llevaron a Bogotá 11.985 pesos, once tomines y tres cuartos de granos, sin dejar de pagar los gravámenes "en el interior, al tiempo de la recolección de consumo de los frutos, en el comercio de una Provincia a otra, y en la exportación de puerto a puerto por las aduanas, a los que se agregaban otros derechos municipales que se exigían en los cabildos de las ciudades y villas". ${ }^{24}$

Sobre la hacienda regional recayeron medias cuotas de empleos, epavas, multas, tributos, comisas, retenciones, ventas de oficios, balas, temporalidades, pulperías, aguardiente, tabaco, pesca de perlas, lanzas, papel sellado, alcabala, diezmos y primicias, almojarifazgos, sisas y armadas de barlovento. No hay que olvidar los pechos por saldo, naipe, pólvora, la amonedación de oro y plata que embarazaban el comercio interior, las gabelas por toneladas, cacerías y derechos de importación que incidían sobre el comercio exterior.

El más gravoso de todos estos impuestos fue la alcabala. Caía sobre indios y españoles, sobre bienes raíces, mercancías y actividades comerciales. Multitud de artículos quedaban bajo ella. "Los que producía la pequeña industria de los pobres y por los que no se había pagado antes; se comprendían muchas cosas que hasta entonces se ha-

\footnotetext{
${ }^{23}$ Ortega Ricaurte, Enrique. Op. cit.

${ }^{24}$ Boletín Historial. Representación del Comisario Regio Del Antonio de Villavicencio. Cartagena: 1916.

28
} 
bían juzgado exentas". ${ }^{25}$ Alcabala y estancos de aguardiente y tabaco dieron origen a una costosa policía de vigilancia que abusaba donde aparecía, injuriaba, chantajeaba, ultrajaba a las mujeres, incendiaba hacerlas enteras o maltrataba a las personas que tenían la desgracia de padecer dichos tributos.

Las disposiciones sobre estancos de aguardiente afectaron al Chocó en grado sobresaliente. Se restringió el sembradío, subió el precio de la miel y se extinguió la venta de anisado. En 1810 habían desaparecido los cañaduzales de muchas regiones como los de Nauritá e Ichó, hasta el punto de comprarse un frasco de miel por un castellano de oro, estimulándose la fabricación de aguardiente de contrabando, según cuenta el gobernador Ramón Diego Jiménez, en uno de sus informes. ${ }^{26}$ El cierre de los estancos desparpajó a los cargueros del Tambo, La Brea y Calima, que ganaban tres patacones por cada tercio arrastrado en los istmos y montañas.

A los traficantes o mindaláes se les imponía un real en Andágueda, por los víveres que introdujeran para el sostenimiento de los pueblos. El comerciante de Citará, Nóvita y Sipí daba el estipendio de un real por cada cerdo, y medio real por el uso de las balanzas oficiales. Las tesorerías de los puertos de Bagadó controlaban los efectos que entraban del Cauca por Chamí, en tanto que la de Citará, con vigías y ayudantes, producían, en tiempos del virrey Salís, cien pesos mensuales por las ropas y tercios que venían del Reino de la Sabana de Bogotá o de los puertos del Callao.

Además de los impuestos por el peaje y cruce de los ríos, estaba el gracioso donativo per cápita que cobraba Popayán. De tantos tributos que se echaban en guerras ultramarinas, en afianzamiento de monarquías, en quemar herejes, en armarse contra turcos, en atuendo de virreyes, y en sueldos de oidores, en perseguir sobre los mares goletas de contrabandistas, sólo quedó el grito de "viva el Rey y abajo el mal gobierno", dado por los esclavos del Patía, cuarenta años antes que lo usaran Galán y sus hombres en el oriente de Colombia.

\footnotetext{
${ }^{25}$ Archivo Nacional. Salón de la Colonia.

${ }^{26}$ Archivo Nacional. Salón de la Colonia.
} 
Rogerío velásquez

Terratenientes y comerciantes de anzuelos, trompas y agujas, cargueros, bogas y peones, no estaban en condiciones de sostener un tren de gabelas como las señaladas. Alimentados deficientemente, mal vestidos y peor alojados y sometidos a un régimen político centralista que impedía el desarrollo de las Provincias, el Chocó tenía que sublevarse en busca de la revisión de sus recursos, doblar la producción de "caldos", hacer más hombre al esclavo, más prepotente al rico, y brindar oportunidades insospechadas a todos los que acampasen en su suelo.

\section{e) La educación}

Una de las causas del atraso y pobreza de los habitantes del Chocó fue, hasta 1810 , la falta de conocimientos adecuados en ciencias y artes que permitieran a la comunidad preparar las producciones espontáneas que brindaba la naturaleza. La metrópoli se había hecho sentir en la entrega de los terrenos llamados realengos, en el hostigamiento de los indígenas errantes, pero nunca en el desarrollo de las industrias que tanto se necesitaban. La madre patria en nuestra región no buscó jamás la causa del estancamiento comarcano, ni menos la técnica de trabajo apropiada para el ensanche de la factoría.

"En un mundo de preciosísimas producciones qué utilizar, de montes qué allanar, de caminos qué abrir, de pantanos y minas que desecar, de aguas qué dirigir, de metales qué depurar", ${ }^{27}$ como apuntaba el arzobispo-virrey, nadie enseñó a "observar la naturaleza, ni a manejar el cálculo, el compás y la regla, ni tampoco métodos para discutir y entender el ente de razón, la primera materia, y la forma de la substancia". ${ }^{28} \mathrm{Ni}$ ciencias exactas ni especulativas conoció el pueblo. La armonía del conjunto estaba ceñida a normas, sistemas y procedimientos inadecuados para aumentar la población, la baja productividad de los comerciantes y conjurar el hambre que mermaba vigor a la comunidad.

Nadie preguntó, por ejemplo, si la pala y el arado eran más convenientes que las manos peladas o las coas en las faenas agrícolas, o

\footnotetext{
${ }^{27}$ Giraldo Jaramillo, Gabriel. Op. cit.

${ }^{28}$ Hernández de Alba Guillermo. Aspectos de la Cultura en Colombia. Biblioteca Popular de Cultura. 1947. 
si el carguío en la espalda de los esclavos rendía más que las ruedas o los animales de tiro. En una comarca de ata temperatura y de humedad que dañaba el cuero y podría los metales, los colonizadores no pensaron en dominar el ámbito que los sustentaba, ya con el abecedario, o bien con normas económicas que produjesen ingresos aceptables. En Barbacoas o La Concha, en Carmelo o Los Tres Brazos de la Santísima Trinidad, el español excitó las posibilidades chocoanas, a caballo de los nativos que padecían por la voracidad del capitalismo.

Sin puertos los mares y las selvas sin caminos; sin pueblos los ríos y los montes sin cultivos; ociosos los canales y la parte social y humana empecinada en inversiones ruinosas o escasamente rentables, la provincia de los chocóes tuvo por denominador común la ignorancia que abarcaba la solución de los problemas del campo, de los centros, urbanos, el gobierno, la propiedad territorial, el mercado y el comercio. La reforma de la estructura, el logro de iguales oportunidades para todos estaba en la letra pura o en su espíritu, en el libro revisado por censores, pero siempre capaz de dar un nivel de vida más armónico con la dignidad de los americanos.

La instrucción libresca que se proporcionaba en las grandes capitales, nada tuvo que ver con el Chocó. Las escuelas privadas y hogareñas que se establecían a diario en otros puntos del virreinato; las creadas por cabildos y dirigidas por seglares, de que habla la Novísima Recopilación de Leyes de España, no se asentaron en nuestro medio. Con estos instrumentos se habría fomentado

(...) la perfecta educación de la juventud en los rudimentos de la fe católica, en las reglas del bien obrar, en el ejercicio de las virtudes, y en el noble arte de leer, escribir y contar, cultivando a los hombres desde su infancia y en los primeros pasos de su inteligencia, hasta que proporcionen en su vida para hacer progresos en las virtudes, en las ciencias y en las artes. ${ }^{29}$

El cuadro de la incultura regional debió de ser tan alarmante que, en 1744 se publicó una Cédula Real con miras a elevar la sabiduría de los que transportaban caudales, pagaban derechos de embarcaciones

${ }^{29}$ Bohórquez Casalla, Luis Antonio. La Evolución Educativa de Colombia. Bogotá: Publicaciones Cultural Colombiana. 1956. 
Rogerío velásquez

menores o por nacer contratos con los blancos. Para la alta clase, bastaba saber que a la plebe se le enseñaban las oraciones del cristiano, obligándole a confesar sus pecados en las festividades de los santos que reposaban en los minerales. Leer y escribir, sobraron. Las notables artes de leer, escribir y contar fueron reputadas como actividades perniciosas, o motivos de desobediencia o de pérdida de tiempo. Es cierto que desde 1503 se prescribió a los gobernadores la enseñanza de las primeras letras al indígena.

Otrosí, mandamos - decían las Instrucciones a Ovando-que luego haga hacer en cada una de las dichas poblaciones e junto con las dichas iglesias, una casa en que todos los niños que hubiere se junten cada dos veces para que allí el dicho Capellán les muestre a leer e escribir, e santiguarse, e sigan la confesión o el pater noster o el Credo e Salve Regina. ${ }^{30}$

Hasta 1803 estos deseos de los reyes no se realizaron en nuestra tierra. El olvido de la lengua nacional que se buscaba, trató de hallarse en Lloró y Quibdó con escuelas de primeras letras pagadas por los escolares, caciques, gobernadores y mandones de los caseríos señalados. La guerra de la independencia cortó el plan propuesto por el visitador Carlos Ciaurriz.

Por el golfo de Urabá las letras se enfrentaron con serios obstáculos. Los agustinos, entre otras comunidades, con celo apostólico y dedicación insuperable, se propusieron aprender la lengua de los cunas para administrar más tarde, con provecho, los santos sacramentos. En tarea tan prolija no se olvidaba el castellano que servía, entre otros menesteres, para mantener la distancia entre españoles y nativos, sostener la tutela sobre el indio, y oponer, como barrera, el dialecto aglutinante de los daríenistas contra la rapacidad de los aventureros.

Los indios nobles, sin embargo, tuvieron colegio en Toro, es los finales del siglo XVIII. La escuela que nació convertida en resguardo, se extinguió dejando cansancio en los recogidos y vagas noticias católicas. Al final, la indiada regresó a luchar contra los opresores que se parapetaban en una moral acomodaticia, en un rango social dudoso y

\footnotetext{
${ }^{30}$ Gómez Hoyos, Rafael. La Iglesia de América en las Leyes de Indias. Instituto Gonzalo Fernández de Oviedo. 1961. 
en una economía inestable con la que se humillaba constantemente a chancos y coronados, totumas y chocóes.

Si la nobleza americana gastó cátedra de lectura y escritura, aritmética elemental, latín y gramática, los demás componentes sociales, en montoneras y bohíos, recibieron prédicas morales para alcanzar el paraíso. Así en Supía y Marmato, Dagua y Cabo Corrientes. Por lo superficial de la enseñanza, leles y mohanes, sin entender la razón de los diezmos y tributos que pesaban sobre cerdos, lechones y palomas, quemaron y asolaron y regresaron a sus antiguas ceremonias. Como en la costa del Pacífico, en 1646, en el Darién hubo mártires descoyuntados, sacerdotes atados y atravesados con lanzas, funcionarios sagrados carbonizados y estropeados, pastores degollados y ludibriados por bebedores, hechiceros y brujos sopladores. ${ }^{31}$

Americanos enemigos del trabajo, admitieron la esclavitud del africano y elaboraron racionalizaciones específicas para justificar su papel de amos, amparados en la piel, la religión y la política, y en resabios burgueses. Poder, riqueza, bienestar -se decía- deben vedarse a gentes de color. El negro, para los grupos encumbrados, carecía de inteligencia, aplicación, buen carácter, cuando no aparecía como desmoralizante y peligroso en medio de la sociedad. No convenía, pues alfabetizar a los mineros que se habían traído como cimiento del orden económico.

Los africanos, con todo, sin habituarse a su posición, solicitaron escuela.

Desearon modificar el atraso de la Provincia vecinos de Nóvita, para lo cual se dirigieron al gobierno central, en 1802, para que se les proveyese de escuelas primarias en donde sus moradores e indios aprendieran la religión y las letras y las prácticas estatales. ${ }^{32}$

La petición no fue atendida. El pueblo llano, la cabeza servil, debía asimilar las costumbres de sus superiores y conformarse con los sentimientos y creencias que se les infundía entre martirios y evasiones.

Los días coloniales chocoanos transcurrieron sin luces en minería

${ }^{31}$ Arcila Robledo, Gregario. Las Misiones Franciscanas en Colombia. Bogotá: Imp. Nacional. 1951.

${ }^{32}$ Nieto Lozano, Danilo. La Educación en el Nuevo Reino de Granada. Bogotá: Editorial Santa Fe. 1955 
Rogerío velásquez

y agricultura, en cabotaje e industrias caseras. No hubo telares, ni ruedas, ni caballos, ni buques. Fuera del monopolio de los metales y de las tierras ribereñas, primó, por aquel tiempo, la ley que se violaba por los superiores del gobierno, o que se hacía sentir con todos sus rigores en los tumbaderos y entables. Crecer, fabricar y transportar no fueron lecciones que se dictaran en nuestra comarca, como sucedía en Bogotá, Quito o Buenos Aires.

Ni pastoreo ni obraje, ni orfebrería ni corrales. Ni cueros, ni trapiches, ni cultivos de café, algodón o cacao. La penetración a lomo de hombres o en embarcaciones primitivas, no podían ampliar el porvenir. Los yacimientos de plata y cobre, la pesca en grande escala, la búsqueda de raíces y de palos tintóreos, no florecieron por las antipatías de las castas dominantes. Lo mismo ocurrió con la habitación, puertos y geografía urbana. Tal vez los señores desconfiados y recelosos que manejaban el territorio y que se combatían entre si, pensaron que hombres nacidos en manantiales y tierras vírgenes, debían aprender a callar y a obedecer para sostener de esta manera el equilibrio del virreinato.

Pero la vitalidad de los caídos estaba en su hermetismo, en su frugalidad, en los segmentos que integraban su mundo. Las viejas esencias de la libertad estaban en el temple de los ríos, en los indios, en los moldes del payanés que creía en la rebelión, en la contumacia de las botas libres, en la individualidad del africano. El pasto espiritual que faltaba en el pueblo y que había pedido en repetidas ocasiones don Carlos de Ciaurriz, empujaba a los bárbaros a ver el mundo con sus propios ojos, y a aceptar, contra el Estado, que los había degradado, vendido, jugado y traicionado, a acción punitiva de la violencia que se sentía llegar de cien puntos diversos. 


\section{LAS CLASES SOCIALES}

\section{a) La nobleza}

Los empleados del virreinato en el Chocó constituyeron la nobleza. No fue la tal originada en la sangre o en títulos del soberano, pues, Ots Capdequi, investigador de estos asuntos, dice a propósito:

Ni siquiera las primeras noticias llegadas a la Corte del hallazgo extraordinario de unas islas misteriosas que el destino había interpuesto en las rutas marinas del primer Almirante de las Indias, hicieron mella importante en el ánimo de los gobernantes ni lograron provocar el entusiasmo de las clases sociales aristocráticas. ${ }^{33}$

Lo preclaro de tantos busca tesoros fueron los gajes otorgados, gracias a los tiempos que se vivían, a la psicología del pueblo español y a la índole colonizadora de las tierras americanas.

Estos empresarios, al mezclarse con otras razas claras, produjeron la jerarquía del territorio. Debajo de ella quedaron adelantados, conquistadores, descubridores y, pobladores ultramarinos, aunque "fuesen hijosdalgo de Indias", como reza la Ordenanza 99 dada por Felipe II. Estas nuevas familias avasallaron los comandos y ventajas, para fomentar, a su manera, el avance del país que poblaban y cultivaban en forma ilógica y anormal, o, bien entre tensiones y torturas que producían la inestabilidad, la confusión y la anarquía en el empleo del esfuerzo y de los recursos disponibles.

Tasando precios y controlando champanes; organizando arriendos y monopolios o suministrando ornamentos para las iglesias; vigilando el cumplimiento del decreto que concedía permiso al Darién para comerciar con la Española; pesquisando contrabandos de plata, oro, monedas, esclavos, armas y guanines conforme a la ordenanza de 1504, o pensando en diezmos señalados en la Cédula de Talavera de 6 de julio de 1540, los delegados de los reyes se dividieron la tierra. Poya y Tatamá, Noanamá, Citará y Baudó los vieron en todos los puntos

${ }^{33}$ Ots Capdequi, José María. Manual de Historia del Derecho Español en las Indias. Buenos Aires: Editorial Losada. 1941. 
Rogerío velásquez

cardinales engrosando su patrimonio, sin importarles los juicios de residencia, las cárceles o los dictámenes adversos contra su honestidad que lucharía por obrar en armonía con la moral del cristianismo.

Aunque no trabajaban físicamente, nunca descansaban. Cuando se concluía una cuestión, aparecía otra. Si no era el tributo indio, era el recaudo de la Bula de la Santa Cruzada para allegar fondos para vencer a los infieles. Reposando el ánimo se entraba en quintos reales derivados de plata, oro, plomo, estaño, azogue u otro metal. Españoles hubo para examinar documentos relacionados con la consecución de esclavos, otear costas, etc. Al cansarse de esto, soñaban con pensiones y repartimientos lejos de la manigua, o con olivares y viñedos en la tierra natal, ya que en este refugio el vino escaseaba con frecuencia, la carne, cuando había, se alteraba, la sal se corrompía, las botas y las lanzas se llenaban de moho, y el calor y las, plagas no permitían soñar en cosas grandes.

Por el cobro de tributos varias veces; por venalidad; por especulaciones con artículos de consumo; por deportaciones de indios; por abusos de autoridad al aplicar las instrucciones de los reyes, de 3 de octubre de 1558 , donde se ordenaba "a españoles, indios y mestizos vagabundos juntarse y poblar", ${ }^{34}$ para contribuir de esta manera a la grandeza de la colonización, ociosos y vagos que vivían del juego, sin casas de habitación ni domicilio fijo; los desplazados de ladroneras y montañas; los que habían olvidado los oficios aprendidos en la madre patria, además de indios y negros, odiaron a esta clase que derivaba su ingreso del ejercicio de gentes que, sin alimento, metían sus humores, sus enfermedades y su alma en los huecos de los canalones, en los maizales, o encorvaba las uñas en la extracción de raíces, cáscaras y frutos.

No menguaba en nada la valía del empleado la consecución de las prebendas por dádivas o compras. Entre los que comerciaban caseríos, aparecen alguaciles mayores y alféreces mayores, escribanos de gobernación y escribanos de cabildos, escribanos públicos y del número, y escribanos de minas y registros, y jueces de la Real hacienda. Caudillos, justicias, procuradores y mayordomos, fiscales que

\footnotetext{
${ }^{34}$ Puga, Vasco de. Provisiones, cédulas e instituciones de su majestad. México: Impresor José María Sandoval. 1878

36
} 
no fiscalizaban, protectores de indios que no protegían, tenientes y gobernadores, cierran la lista. Con el sueldo se res repartían solares y tierras de estancias como las que dio, en 1535, Alonso de Heredia y que historia Castellanos:

"Señalan plazas, calles, pertenencias, al norte, sur, oriente y al ocaso".

Esta era la nobleza que en los días sonados -llegada de un virrey a Bogotá, exaltación de un príncipe al trono, nacimiento de un infantevestía pantalón a la rodilla y largas medias, zapatos con hebilla, casaca larga, abierta en los costados y mangas ajustadas, chaleco lujoso largo por delante, capa española, joyas y adornos. Los vestidos de paño de Segovia o de Béjar se dejaban para lucirlos en España, en donde al calor de vinos de la Mancha o del reino de Sevilla, se pudieran entonar canciones castellanas o gallegas, andaluzas o aragonesas impregnadas de fuerza como la raza misma.

\section{b) Los terratenientes}

De brazo con la nobleza comarcana caminaron los que habían alcanzado las tierras desde 1513 en adelante. Las razones de entregar la comarca a descubridores y pobladores, las resume la Ley $1^{\mathrm{a}}$., tít. 12 , lib. $4^{\circ}$. de la Recopilación, con las siguientes palabras:

porque nuestros vasallos se alienten al descubrimiento y población de las Indias y puedan vivir con la comodidad y conveniencia que deseamos, es nuestra voluntad que se puedan repartir y repartan casas, solares, tierras nuevas en los pueblos y lugares que por el gobernador de la nueva población les fueren señalados haciendo distinción entre escuderos y peones y los que fueren de menor grado y merecimientos, y los aumenten y mejoren atenta la calidad de sus servicios para que cuiden de la labranza y crianza. ${ }^{35}$

La venta de las tierras llamadas "vacas" por el gobierno y las ordenanzas mineras, afianzaron el prestigio de los terratenientes. Pregones como los de Sevilla, en 1511; concesiones y capitulaciones con vasa-

\footnotetext{
${ }^{35}$ Ots Capdequi, José María. Op. cit.
} 
Rogerio velásquez

llos excepcionales y cédulas como las de 1504, 1511, 1529 y 1619, reafirmaron la voluntad de poderío de una casta que nacía con esclavos, $\mathrm{y}$, con parrafadas e influencias, corría sobre los Andes y era dueña de todos los riachuelos de la costa.

Lo aleatorio del producido minero, y los gastos de sostenimiento, llevaron a la Corona a arrendar o vender sus minas ricas o de nación. Españoles, americanos e indios podían conseguir estos entables pagando al fisco el quinto correspondiente. No debían ser mineros los ministros, gobernadores, corregidores, alcaldes mayores y sus tenientes letrados, ni alcaldes ni escribanos de minas, porque, además de mantener una zona neutral en los conflictos, tenían ellos una cuota mensual que salía del forcejeo de los humildes que, en ocasiones, ni reían ni lloraban, sino que se daban como animales inferiores en el fomento de la inmigración.

Así nacieron los grandes magnates de la costa. Los Tenoríos, en Micay, Naita, Mechengue, Aguaclara, Chuare y Santa Bárbara; los Mosqueras y Arboledas, amos de Timbiquí y gran parte del Alto Chocó; Francisco Parada, fundador por segunda vez de Iscuandé y dueño de Sanabria; los Córdobas y Palomeques, poseedores del bajo Atrato; los Palacios, de Cértegui; los Orobias, de Guapi; los Olayas, de Tapaje y Sanquianga, Satinga y Aguacatal, Nerete y Pulviza; Angulos, Sarmientos, Castillos y Albanes que empuñan el poder en Telembí y sus afluentes. Con ellos se extiende la esclavitud de los africanos hasta Quito y Panamá, abarcando las sierras de Naya, Yurumanguí, Raposo, Calima y Cajambre, pueblos y caseríos donde ejercieron autoridad ilimitada los agentes de Pedro Agustín de Valencia y Sebastián Lanchas de Estrada.

La vida del terrateniente está contada en multitud de documentos por viajeros e historiadores. Sirvió para completar el descubrimiento de la comarca, para trazar los primeros caminos, para avivar el descontento contra España, especialmente entre indios y negros. Casi siempre se caracterizó por la dureza contra los esclavos, por fricciones con otros mineros, por la burla al tesoro público, por sus costumbres disolutas. Al terrateniente se debe el mestizaje racial que comenzó con el indio y se desparramó más tarde sobre la raza africana. 


\section{c) El sacerdocio}

El Chocó, tierra de contradicciones, padeció, hasta 1810, lucha de clases, de sentimientos y aspiraciones. Divergencias por impuestos, esclavos, privilegios y jornales; choques y fricciones por una economía sin saldo favorable para proyectarse sobre el virreinato, crearon grupos que se aniquilaban por gajes lejanos o por simples caprichos de los colonizadores.

El papel preponderante de la curia, que buscaba en nuestra región extinguir la magia, el tótem y el fetiche en negros e indios, se vio deslustrado por el demonio de las ambiciones. La riqueza mineral la codicia de los capitalistas de otras regiones, el deseo del clero de otros sitios que anhelaban disfrutar de los curatos, hizo nacer la malquerencia contra los misioneros. Los primeros en sufrir el choque de fuerzas extrañas fueron los candelarias, que abandonaron el bajo Atrato en 1636. Bucaneros piratas y negociantes que conculcaban las reales disposiciones al trasegar por el gran río, impusieron la necesidad de su retiro. Años más tarde, franciscanos y jesuitas hicieron otro tanto por la defensa de la vida.

En 1689 dejan el país los jesuitas. Comprendiendo que servían de obstáculo a la expansión de las oligarquías seccionales, se marginaron en las selvas del Amazonas. De ahí en adelante desaparece adelante desaparece el convento de Toro, volviendo las tribus que se domesticaban con la doctrina oral al vagabundaje y a las fallas culturales anotadas por fray Juan de Quevedo en la silla episcopal de Urabá, creencias y supersticiones descritas minuciosamente por fray Pedro Simón en el tomo I de sus Noticias Historiales.

La curia se enfrentó a la selva y a los naturales que creían en deidades que atraen el rayo y la lluvia, aumentan la caza y la pesca, desbordan los el torrentes, dan o curan las enfermedades y alimentan los cultivos. Después luchó con los altos empleados, con gobernadores que embarcaban frailes a Cartagena o los encarcelaban, como procedió Carlos Alcedo y Sotomayor con el franciscano Juan José de Córdoba, en 1681. Representantes del imperio como se creía el sacerdocio, no podía dejar violar sin querellas ni algazaras las instrucciones impartidas a Nicolás de Ovando en 1504, ni las voces de Alcalá de Henares 
Rogerío velásquez

y Zaragoza en 1503, ni menos las ordenanzas de 1554, que buscaban la grandeza interior de esos que se consumían bajo tercios de cuatro arrobas sin más alimento que plátano y harina de maíz.

"La iglesia española en la Colonia, dice Eduardo las Mendoza Varela, si exceptuamos breves intervalos, el no fue tan solo un Estado dentro del Estado, sino un gobierno por encima del mismo gobierno". ${ }^{36}$ Por esta razón, los doctrineros acusan a los gobernadores por retención de sueldos. Así lo hizo el presbítero Luis Antonio de la Cueva, en 1672. Después de demostrar al Juez de Residencia que tenía permiso de la Audiencia de Santa Fe para enseñar a los indios de Noanamá y el Raposo, San Lorenzo de Supía, Paya y Citará, enumera los riesgos vencidos en las provincias citadas, su valentía de fundador de Cajamarca, y poblador de Tatamá y Noanamá, para concluir pidiendo el pago de sus servicios como plantador de la fe entre bárbaros que servían a militares en zonas de provincia.

Por minas también hubo jaleo. En Santa Bárbara de Iscuandé se acusa al sacerdote Francisco Rugi, de la compañía de Jesús, por "llevarse los indios con ciertos pretextos de que les quiere enseñar la doctrina, para, en el río de Timbiquí, servirse de ellos sacando oro". ${ }^{37}$ Sacerdotes mineros fueron Francisco de la Parra, de Santa Bárbara de Nóvita, Clemente Miranda, de Yalí, Rafael Antonio de Cerezo, de Nóvita y Tadó. En esta empresa rivalizaban con alféreces, maestros de campo, descubridores y colonizadores que se repartían la comarca. "Para detener la ambición sacerdotal -decían los seglares- era necesario providencias como las empleadas en Nueva España, en 1533, antes de que la tierra toda fuese de la curia, como había ocurrido en Méjico de 1570 en adelante". ${ }^{38}$

Litigios hubo entre religiosos por jurisdicción, minas, manejo de caudales y esclavos, incumplimiento de capitulaciones de entradas y funciones, diezmos y primicias. Hijos de su época, amaron el oro, el énfasis, la fuerza. "Dedicados a su negocio", según Francisco Silves-

${ }^{36}$ Mendoza Varela, Eduardo. "Mestizajes y mestizos, un mundo a dos vertientes". Bogotá: Publicaciones de El Tiempo de Bogotá. 1963.

${ }^{37}$ Pacheco, Juan Manuel. “¿Fue un Jesuita el Fundador de Tumaco?” En: Revista Javeriana № 220. Bogotá: 1955.

${ }^{38}$ Bargalló, Modesto. La Minería y la Metalurgia en la América Española durante la época colonial. México, D. F: Fondo de Cultura Económica.1955. 
tre; "con vida licenciosa, y desarreglada hasta convertir el ministerio de edificación en ministerio de perdición"; 39 "pobres y sin letras, lo que los obligaba a hacer cosas indecentes a su estado", ${ }^{40}$ cumplieron, sin embargo, su tarea en lo social, político y económico. En la vida chocoana se les halló acondicionando los hábitos, las ideas y la psicología del pueblo, dando normas y estilos, participando en fiestas públicas y privadas y haciendo obligatorio lo que acrecentaba su poder. Para conseguir lo que deseaban lucharon públicamente contra comerciantes y pobladores, amos y mineros, potentados locales y representantes de España, contra jerarcas de la iglesia y clero llano, con indios, feligreses y negros, contra todo lo que estorbaba el logro de sus aspiraciones.

\section{d) El indio}

La situación social de los nativos era calamitosa en los comienzos del siglo XIX. Hasta 1661 el reconocimiento de la autoridad del Rey, provocaba, en Citará y Tatamá, guerrillas armadas, pactos y compromisos de no agresión que se incumplían con frecuencia. El rancho indígena se vio en las cabeceras de los ríos y en los picos de las cordilleras, en todo lugar que estuviese a salvo de perros caníbales que ganaban sueldos, y de hombres que cobraban impuestos para las instituciones españolas.

Sería un error negar que la acción evangelizadora del sacerdocio no melló asperezas ni costumbres de los naturales. En 1780 Juan Jiménez Donoso los halló "dóciles y simples en su modo de explicarse y de portarse, viviendo sin fausto y sin ambición, adictos siempre a bebidas embriagantes cuyo desorden degenera en lujuria y a veces en supersticiones". ${ }^{41}$ Empero, la dureza de la vida que soportaban los hacía huir de los pueblos del Tigre y Tarena, Cacarica, Calidonia, Cupica y Lloró, Pavarandó y Murrí, sometiéndose a permanecer en despoblado y costas inhóspitas, en cejas de montes sin caminos o en barrancos de tres varas.

\footnotetext{
${ }^{39}$ Groot, José Manue Op. cit.

${ }^{40}$ Álvarez Mejía, Juan. La Iglesia en América. En: Revista Javeriana.. № 220. Bogotá: 1955.

${ }^{41}$ Ortega Ricaurte, Enrique. Op. cit.
} 
Rogerío velásquez

Cerca a las ciudades ejercía oficios varios. Cuando se le arrebataba la parcela, entraba el indio a trabajar en los montes de los corregidores por seis meses, recibiendo en pago, menudencias. "En algunas provincias del Chocó - dice un autor-y especialmente en la de Tatamá, se les llegó a tiranizar obligándolos a llevar cargas a cuestas por ásperas montañas, o por agua en canoas, mal comidos y peor tratados y pagándoles su trabajo con géneros y mercancías que con frecuencia les eran inútiles y siempre se las daban a precios exorbitantes". ${ }^{42}$ El carguío indígena más común se llevaba a cabo de San Juan de Chamí al puerto de Andágueda, en diez o quince días, empleando tres o cuatro naturales en la conducción de tercios que exigían siete $\mathrm{u}$ ocho trabajadores. No llevando alimentación por la imposibilidad de portarla, tomaban los cargueros para su nutrición de los fardos que conducían, gastos que se les elevaba en cantidad de precio, viniendo al fin de la jornada a ganar poco o nada, o a quedar comprometidos a hacer nuevos viajes que esclavizaban para siempre.

En todo esto se incumplían las leyes, especialmente la $6^{\text {a }}, 7^{\text {a }}, 8^{\text {a }}, 9$ ${ }^{a}$ y 10 , tít, $1^{0}$, libro $6^{0}$, que prohibían hacer de los naturales bestias de carga, así lo consintieran. Con el pago de jornales en las formas citadas, se violaban las leyes $2^{\text {a }}$ y $3^{\text {a }}$, tít. $1^{0}$, libros $4^{0}$ y $5^{0}$, para no recordar cédulas, provisiones, pregones y ordenanzas que salvaguardaban su prestigio de súbditos de España.

El miedo a la matrícula; el ser bestias de carga; el robo de sus mujeres e hijas, acción condenada por la reina Isabel el 3 de agosto de 1533; el temor al cristianismo que decía una cosa y hacía otra; el permanecer en pueblos fijos y vestidos y hablar en castellano; la represión de sus bebezones y sus dioses, estimularon, primero, el odio al peninsular o al blanco en general, a los mestizas y criollos, negros, zambos y mulatos, y, después, en forma abierta, la guerra sin cuartel.

\section{e) EI negro}

La base de la pirámide social estaba formada por negros que valían menos que los indios. Esclavos como los moros, sus descendientes

${ }^{42}$ Arboleda Llorente, José María. El indio en la Colonia. Bogotá: Prensas del Ministerio de Educación. 1948. 
estaban sujetos a los sufrimientos del titulaje. En las ciudades o en los campos eran bienes terrenos de otros hombres, cosas como el ganado o los cerdos, brazos para explotar o sembrar, bueyes que servían sólo para construir heredades de poderosos y letrados.

Jurídicamente todo el mundo podía conseguir piezas de ébano. Mayores o menores de edad, varones y hembras, capaces e incapaces, nacidos o por nacer, americanos o españoles europeos, seglares o eclesiásticos, civiles o militares, nobles o del fuero común. Al feto se le conseguían siervos para cuando pudiese gobernarlos. Para ser amo en Tierra Firme, bastaba con nacer vivo, respirar veinticuatro horas naturales, tener forma de hombre sin miembros de bestias, ser bautizado antes de que muriese. La Ley XVI, tít. VI, partida VI, lo disponía de esta forma.

Comprado con oro sellado, tejos, oro en polvo o plata pura, lotes de tabaco, azúcar, cacao, arroz, maíz, raíces, carnes o plátanos, se le marcaba en la espalda, cadera o pecho, con letras o señales de los amos. Esta costumbre había sido corregida por Carlos III, el 4 de noviembre de 1784, pero en el Chocó subsistió hasta 1800. Para inutilizar las marcas de carimbar en nuestro territorio no habían valido rebeliones africanas, desórdenes pueblerinos, el labrar silencioso en minas y sementeras, el oro levantado en todas partes.

El africano soportó castigos excesivos. Por el robo de una esperma; ${ }^{43}$ fugas que se castigaban con heridas que se cauterizaban con ají, fuego y sal, o con collares de hierro que se soldaban sobre el cuello, además de los celebrados perros de presa, cepo y látigo, los grilletes y las marcas, el pregón, el tumbadero y las campanas, los cortes de orejas y narices, piernas y corvejones. Por algo se decía "que la cabeza servil carecía de derechos".

Lo inhumano de los superiores condujo a los africanos a toda suerte de locuras. Se paralizaron las minas $y$ las siembras, o se buscaba con ahínco la carta de rescate, miraje ilusorio si se considera que la tal valía de tres a quinientos patacones que, si se recogían en las faenas de los días de fiesta, con limosnas y regalos, el amo recibía el dinero y retenía la libertad. Cuando el esclavo demandaba, si se atrevía a

${ }^{43}$ Posada, Eduardo. La Esclavitud en Colombia. Bogotá: Imp. Nacional. 1935. 
Rogerío velásquez

ello, el señor negaba haberlo recibido o confesaba diciendo que el manumiso se lo había robado. ${ }^{44}$

En gran número se registraron suicidios por temor a la esclavitud, y asesinatos cometidos por negras en las personas de sus hijos para librarlos de la coyunda futura. En todas partes se vieron negros que pedían ser vendidos a nuevos amos para procurarse vestidos, alimentación y medicina; concubinas que malparían a consecuencia de los castigos; amos que maltrataban a sus siervas para provocar los abortos; infelices, en fin, que mataban a sus superiores ante la imposibilidad de trabajar como muchos para sostener grandes familias.

Para el español que no trabajaba, el esclavo no debía tener otro Dios que su amo, y a él tenía que entregarle el fruto de sus inquietudes. Con hambre física; desnudo; aislado de sus hermanos en raza; en habitaciones lacustres, insuficientes y malsanas; sin medicina; sin poder abrazar profesiones que lo libertase de los zambullideros; peón de canoas, pescador y cazador; sin poder tener a su servicio otros seres que le ayudasen en sus faenas cotidianas; prohibido de casarse con razas claras, asistir a diversiones de españoles o de indios, llevar armas, andar de noche, comprar en villas y mercados; utilizado como moneda en los juegos o como dinero para saldar compromisos comerciales; construyendo pueblos, levantando iglesias, fabricando cárceles, dotando al sacerdocio del sínodo tasado, pero sin disfrutar de sueldos ni solares, caballerías o peonías, llegó a 1810, fecha en que empezó a variar el ritmo de las instituciones del Reino, y con éstas, su existencia.

\section{f) La masa flotante}

La masa flotante de la población del virreinato, estaba formada por gente ociosa "y como tal aplicada a la rapiña y hurtos y otros delitos consiguientes en éstos", ${ }^{45}$ escribió un día el mariscal de campo don Antonio Manso y Maldonado. Entre tantos americanos y europeos pueden situarse a negros e indios que buscaban, al calor de las contradicciones económicas, políticas y sociales, evadirse del gobierno que emanaba de España.

\footnotetext{
44 Rojas Gómez, Roberto. "La Esclavitud en Colombia". En: Boletín de Historia y Antropología. Año XIV. N 158 . Imp. ${ }^{\mathrm{Na}} \mathrm{ciona}^{1} .1922$.

${ }^{45}$ Giralda Jaramillo, Gabriel. Op. cit. 
El cuadro debió ser inquietante, si nos atenemos a las consideraciones del arzobispo-virrey, que dice:

Se ven fertilísimos valles, cuya abundancia pide la mano del hombre, más para recoger que para trabajar; y, sin embargo, se hallan yermos y sin un solo habitante, al mismo tiempo que se pueblan las montañas ásperas y estériles de hombres criminosos y forajidos, escapados de la sociedad, por vivir sin ley ni religión. Bastaría delinear un abreviado mapa de la población del Reino para que se conociese la confusión y desorden en que viven estos montaraces hombres, eligiendo a su arbitrio y sin intervención del gobierno, ni de los jueces subalternos, el lugar de su retiro, tanto más agradable para ellos cuanto más apartado de la Iglesia y de su pueblo. Esto nace de la antigua y arraigada libertad de huirse los unos de los otros para poder vivir a sus anchas y sin recelo de ser notados en sus infames y viles procedimientos. Los hombres medianamente acomodados se llaman aquellos que por falta de providencias precautivas de la demasiada agregación de tierras en un solo sujeto, han podido a viles precios adquirir inmensos terrenos en que por lo regular tienen como feudatarios a los de inferior fortuna. Los primeros perseveran más arraigados a sus posesiones por la ganancia que reciben de sus esparcidos domésticos; pero estos, que forman el mayor número de habitantes libres, hacen propiamente una población vaga y volante que obligados de la tiranía de los propietarios, transmigran con la facilidad que les conceden el poco peso de sus muebles, la corta pérdida de sus ranchos y el ningún amor a la pila en que fueron bautizados. Lo mismo tienes donde mueren que donde nacieron, y en cualquier parte hallan lo mismo que dejaron. ${ }^{46}$

Gentes alzadas como las del Sinú y Cartagena, descritas y apaciguadas por Antonio de la Torre Miranda; negros dispersos en el golfo, Cana y Panamá; africanos huidos por ríos y quebradas que paraban en istmos donde inquietaban con sus rapiñas y depredaciones; indios confinados como los de Cacarica que, al llegar a Juntas del Tamaná, se volvían vagabundos amparados por los montes; barbacoas escondidas y lejanas, como las que vio Alonso de García en la Villa de Anserma; ${ }^{47}$

\footnotetext{
${ }^{46}$ Giralda Jaramillo, Gabriel. Op. cit.

${ }^{47}$ Ortega Ricaurte, Enrique. Op. cit.
} 
Rogerío velásquez

ociosos y vagos que vivían del juego, sin casas de habitación ni domicilio fijo; hombres enojados con la Corana, porque, habiendo olvidado los oficios aprendidos en Europa o América, eran obligados a alquilarse en los trabajos diarios, recibiendo el jornal que mandaba la ley $1^{\text {a }}$, tít. XII, libro VI de la Recopilación, desearían acabar con "la dureza y rapacidad de los agentes del gobierno, con las arbitrarias detenciones y reconocimientos en los tránsitos, con las dificultades de obtener pronta justicia rebajando los costos de los pleitos, y dar fin al engreimiento de los ministros y jefes superiores que odiaban a los naturales". ${ }^{48}$

Entre esta masa flotante pueden incluirse a piratas y bucaneros que visitaron la comarca. El oro de Cana, Quibdó y Antioquia propiciaron estas incursiones. Sir William Paterson y sus acompañantes en 1698 no deben colocarse en esta lista, pues, el inglés, pensaba asentarse en la tierra para "arrebatar las llaves del mundo a España, haciendo de su fundación un puerto libre en donde no existiesen diferencias de partido, de religión o nacionalidad". ${ }^{4}$

Verdaderos corsarios fueron Francisco Drake y Juan Hawkins, quien se posesiona del golfo en 1563 con negros guineínos; Francis L'Olloneis, muerto en las desembocaduras del Atrato a manos de los indios; Lionel Wafer y Guillermo Dampier, en 1680; el capitán Long, que enarbola la bandera inglesa en Trigandí, en 1689; Wernon, en 1745; Miguelillo, San Martín y compañeros, en 1758, los que ejecutaron muertes y latrocinios en las personas de los indígenas. ${ }^{50}$

Bajo el mando del francés Coxon, en 1679, Hawkins, Sharpe y otros traicionados por Morgan en Panamá, llegan a la provincia del Darién. Indios de este lugar habían informado la posibilidad de atacar a Chepa, cerca de la mar del Sur. Al oeste de la desembocadura del Atrato deciden atacar a Santa María, defendida por una guarnición de 400 españoles. Con banderas rojas, armados de pistolas y puñales, garfios y mosquetes, atravesando bosques, ríos y plantaciones, preci-

${ }^{48}$ Banco de la República. Proceso histórico del 20 de Julio de 1810. Bogotá: Documentos. Imp. del Banco de la República. 1960.

${ }^{49}$ Restrepo Sáenz, Eduardo. "Los escoceses en el Darién”. En: Boletín de Historia y Antropología. Año XVIII. N 209. Bogotá: Imp. Nacional. 1930.

50 Hernández B, Ernesto. Urabá Heroico. Bogotá: Editorial A B C. 1956. 
picios perpendiculares y sierras empinadas, tomaron el pueblo, después de hacer veintiséis bajas y de dejar sesenta heridos. Hubo escaso botín. En esta ocasión intervinieron los indígenas por venganza contra el gobernador español que se había robado la hija del cacique del Darién, a quien tenía por esposa. ${ }^{51}$

Botas libres, en 1679, entraron al Chocó, por el Atrato, Coxon y Cook, con 600 hombres, remontaron el río arrostrando penalidades y ataques de los naturales, hasta el real de minas de Quibdó, apresando españoles que se ocupaban en el cambio de oro.

Los expedicionarios portaban sendas fuertes maletas para cargar el oro que consiguieran en la aventura; pero siendo combatidos por las gentes y por los indígenas, por la naturaleza que les era hostil, regresaron sin tesoro y malferidos a buscar sus embarcaciones de mar, que habían dejado en las bocas del Atrato. ${ }^{52}$

En 1703, cuenta Jiménez Donoso,

la armada inglesa con pocos efectos de su poder costeaban sin oposición hasta en la América, y sin tener suceso feliz, doscientos ingleses, esperando mejor fortuna, entraron por el golfo del Darién, y poniendo pie en tierra pasaron a Antioquia, con ánimo de saquearla. El gobernador que no recelaba este peligro se halló sin soldados españoles para la defensa, y animando a los indios se armaron como mejor pudieron con palos, tostadas las puntas, piedras, algunos con espadas y lanzas, aunque pocos, todos los cuales dieron sobre los enemigos con tanto valor, que no sólo evitaron su daño, sino que enteramente los derrotaron, sin que se escapase uno de sus manos..$^{53}$

Indios y negros, mulatos y mestizos, tuvieron, frente a corsario s y bucaneros, conducta cambiante. Acorralados como estaban, buscaban un escape. Con la Corona o contra ella, parecía ser el grito de españoles rapaces, de nativos que vivían ajenos a la vida nacional, de mulatos escandalosos y viciosos, y de africanos aptos para golpear con los cerrojos de su jaula, a la derecha o a la izquierda.

51 Esquemelin John. Piratas de América. Buenos Aires: Editorial Colombia. 1945.

52 Restrepo Vicente. Estudio sobre las minas de oro y plata de Colombia. Bogotá: Publicaciones del Banco de la República. Imp. del Banco de la República. 1952.

53 Ortega Ricaurte, Enrique. Op. cit. 
Rogerio velásquez

- III-

\section{Las rebeliones de la plebe}

Indios y negros, por el tratamiento recibido, dieron señales de vida. No sabían ellos que con los movimientos revolucionarios se debilitaban los resortes esclavistas, los lazos familiares, la iglesia y el obraje, la prepotencia de los mandatarios. Sin embargo, sentaban su protesta por el trabajo obligatorio en los días de fiesta, para decir, a voz en cuello que no podían atender el sostenimiento de la parentela con el estipendio de un real, o para informar a las clases privilegiadas que no aceptaban los gravámenes por el lavado de las escorias del río, cazar o pescar, o por los pechos que se extraían a cada esclavo que dejaba de concurrir a los minerales. Los de abajo sabían, con todo, que cada brote de descontento se castigaba con ventas a la carrera de los revoltosos, o bien con cuerpos descoyuntados, ensangrentados y en patíbulos.

Con la ninguna medicina, aparecía la historia del vestido. El negro, por ejemplo, cubría sus desnudeces con trapos regalados por los amos: calzón de fula para los días de misa, taparrabo para los comunes y bayeta para las mujeres. En esto se seguía la costumbre americana de ver a los africanos en

(...) rancherío diseminados entre aquellos bosques espesos, ciénagas y caños, sin vestidos, de que no necesitaban por no tener vergüenza, pues sólo las mujeres se ponían un escaso guayuco en la cintura o un tetero hecho con "un pañuelo grande que se estaban por dos de sus puntas sobre la nuca y por las otras dos en los lomos, formando por delante del pecho un velo undoso y desleal que hacía traición, cuando no al calor, al volumen". ${ }^{54}$

Cara a estas necesidades nacieron los conflictos sociales. Crítica, insatisfacción, ansias de tener tanto como los demás, ilusión de reglamentar el trabajo y de acabar con lo existente. Para tener derechos como persona humana, ocupaciones y medios de mejoramiento gradual, el de Zambeza o Costa de Oro siguió, cuantas veces le fue posi-

54 Espinosa, Mario. Op. cit. 
ble, los ejemplos de Boyano y Mozambique en Panamá, o la lección de San Basilio de Palenque en la caribe Cartagena.

Porque daba lo mismo morir en la pesca de perlas, mina o navegación o huyendo de la ira de los terratenientes. En este último caso se perdía, la lengua, las orejas o los miembros genitales, o se mataba de frente al dueño de los entables, al capataz o corregidor. A individuos que no

(...) destinaban un grano de oro de sus propiedades para el sostén de misioneros que llevaran a los salvajes independientes, y mantuvieran, entre los negros esclavizados, la luz del cristianismo; a los que no favorecían hospitales donde pudieran refugiarse los negros inutilizados por el largo servicio; a los que no fundaban escuelas donde los niños esclavos se hicieran medio racionales; a los que no velaban por lugares donde pudieran residir autoridades que vigilaran los tesoros extraídos diariamente; a los que no daban para prisiones dónde regenerarse los criminales; ni para mejoras que hicieran menos insalubres aquellos climas enervantes, ni para vías dónde penetran el comercio y la industria y la civilización,

(...) a tales hombres se les podía hacer la guerra, destronarlos y extinguirlos si fuera necesario. El Chocó, tributario del Cauca, aprendió de Cali a defenderse. Los sucesos de 1536, 1602, 1743, 1775 y 1778, relatados por cargueros, bogas y baquianos, sostuvieron el fuego de combatir al Virreinato. Cuando el escándalo trataba de apagarse, lo atizaban Cartago, Buga, Anserma, Caloto y Toro, con la instigación de sus plebeyos. Cartagena, entre tanto, enviaba, junto con sus champanes noticias alarmantes sobre Carlos IV, o sobre su esposa María Teresa de Parma, Godoy o Manuel Mallo, o sobre nuevas y extraordinarias contribuciones para contener a los franceses que irrumpían altaneros sobre España y sus posesiones.

A estos estímulos se sumaban los piratas. Mostrando a las gentes que la metrópoli se podía vencer, contaban, a su manera, lo que ocurría en la Península. Un territorio desvertebrado y desordenado políticamente; mandatarios con diferencias culturales, y reyes maniáticos, débiles o dementes. En América, como secuela de lo anterior, aparecían los sistemas políticos donde proliferaban los impuestos, sacerdotes que luchaban entre sí, castas que se perseguían apoyándose en pala- 
Rogerío velásquez

ciegos venales. En no pocos levantamientos del golfo, los bastardos de la costa, con sus prédicas continuas, fueron decisivos.

Además de lo dicho, muleques, mulecones y piezas de Indias creían con firmeza en la existencia de una orden real que concedía la libertad a los africanos, pero que blancos interesados la retenían para su provecho personal. Esta suposición, errónea tal vez, pero que hizo carrera en el Nuevo Mundo, puso ruido en Antioquia, en 1781. En el Chocó, donde las razones abundaban, la conseja mantuvo los ánimos sobre exaltados y dispuesta la voluntad a la aventura. Esclavos que se mataban para no servir a los amos, como el Jelofe Lepaña, historiado por don Eduardo Posada; esclavos que corrían los peligros del cimarronaje, provocaron disturbios en diversos puntos de la comarca.

Los hechos se agudizaron con la noticia de la obra libertadora llevada a cabo por don Lorenzo de Agudelo, en Santa Fe de Antioquia, Jorge Ramón de Posada, en Marinilla, y Francisco Ignacio Mejía, en Rionegro. La información de lo realizado por los patricios citados, se extendió por el León y Murrí, Bebará y Bebaramá, de boca en boca y de oído en oído, poniendo en predicamento la conducta del gobernador Aguirre, que guardaba, como José Barón de Chaves, en Antioquia, el documento que había manumitido a centenares de personas en Socorro, Sopetrán, Guarne y San Jerónimo.

Los terratenientes, sin quererlo, ayudaron también a las revueltas.

La relajación de sus costumbres y el endurecimiento de sus conciencias, los mantenía alejados de Dios. Consideraban que la evangelización de sus esclavos afectaba su dominio absoluto y se empeñaban, por lo mismo, en mantenerlos aherrojados en las tinieblas tenebrosas de la más absoluta ignorancia. ${ }^{55}$

La vida ruda, aislada y casi bárbara - dice otro autor- que llevaban los colonos en sus aldeas, minas y hatos, en lucha con el calor, la humedad, los insectos y las enfermedades endémicas de los trópicos, sin más ley que sus propios impulsos, puestos al servicio de la necesidad de satisfacer los más rudimentarios y primordiales apetitos

\footnotetext{
${ }^{55}$ Martínez Delgado, Luis. Curso Superior de Historia de Colombia. T. VI. Bogotá: Imp. Nacional. 
de la naturaleza, que era ya embrutecedora forzosamente, ${ }^{56}$ dieron nacimiento al palenque, a los asaltos sorpresivos, a los combates desesperados. Las rebeliones más notables que influyeron sobre los chocoanos, en más de doscientos años de existencia, fueron:

1688. Sublevación de los mineros de Neguá-Los orígenes aparecen sintetizados "en la opresión en que los amos tienen a los esclavos con tan crecido trabajo, castigo y corto alimento que no son capaces de mantenerse ni tener descanso", dice uno de los pacificadores.

Fue tan cruel el sometimiento de los facciosos que de las "muchas minas y esclavos que las labraban, no quedaron más de diez y ocho negros de mina del gobernador Juan Buesso de Valdés y doce del licenciado Miguel Benítez de la Serna, y cuatro de Fabián Ramírez. Murieron muchos y salieron los más de los que escaparon con vida por el socorro del Soberano". ${ }^{57}$

1688. Revuelta indígena de Lloró -"La opresión injusta y el servicio como esclavos, para pagarles en miriñaques y cosas que muchas veces les son inútiles", encendió la sedición. "El tirano Quiruvida y otros que le seguían -como dice el pacificador Carlos Sotomayor y Alcedo- pidieron gobierno propio simbolizado en alcaldes, capitanes, gobernadores o caciques que entendieran su lengua y los ampararan de los corregidores". ${ }^{58}$

Negada la proposición, surgió la revuelta. "El maestro de campo don Juan de Caicedo, ajustició a más de treinta indios de los más soberbios, que al enfermo de accidente violento siempre le aprovecha la sangría". Sin embargo, quedaron los resentimientos, "los ajenos influjos que obligaron a los indios de la región a inquietar a los españoles hasta 1757 ". ${ }^{9}$

\footnotetext{
${ }^{56}$ Garrigó, Roque E. Historia documentada de la conspiración de los soles y rayos de Bolívar. La Habana: Imp. El Siglo XX. 1929.

${ }^{57}$ Ortega Ricaurte, Enrique. Op. cit.

${ }^{58}$ Ortega Ricaurte, Enrique. Op. cit.

${ }^{59}$ Ortega Ricaurte, Enrique. Op. cit.
} 
Rogerío velásquez

1719. Motín del Darién -El odio a los evangelizadores promovió el levantamiento que se vio apoyado por los extranjeros ingleses que merodeban por la costa. El estado de zozobra continuó hasta 1723, fecha en que la indiada pasó a cuchillo a los vecinos de Santa María.

1727. Nueva revuelta del Darién -Es uno de los más célebres motines ocurridos en el siglo XVIII. Tuvo su origen en la mala conducta del sacerdocio y en el tratamiento desobligante dado por las autoridades a los indios. Unos y otros los obligaban, no solamente a hacer rozas de comunidad para su manutención, sino también para negociar con ellas con sus productos; pero lo que más dolía a los indios no era esto, sino que los magnates los apaleaban y hasta los arrastraban de los cabellos, sin que tuvieran libres de ellos ni los mismos caciques y principales del pueblo, lo cual fue disponiendo los ánimos contra el gobierno de la Provincia en términos tales, que sólo aguardaban la primera ocasión para sublevarse contra los españoles.

Agregábanse a esto las sugestiones de los extranjeros que se metían allí en busca de oro y no perdían la ocasión para concitar a los naturales contra el gobierno. Uno de ellos fue un francés llamado Carlos Tibón, que después del primer saco que en 1712 hecho por los ingleses en Santa Cruz, llevándose toda la riqueza y esclavos de las minas, vino con ochenta franceses de los forajidos que infestaban la Provincia, y juntando trescientos indios del Golfo, entraron a sangre y fuego en busca del oro que se había sacado de las minas, y cometieran toda clase de excesos.

En esta revuelta se oyó, por primera vez, el grito de libertar al Darién del poder de los metropolitanos, idea lanzada por el mestizo Luis García, jefe de los amotinados. Aunque la guerrilla fue vencida en Chucunaque, todavía en 1734

los indios de algunos franceses que había de los conjurados con García, bajaron a Santa Cruz de Cana, y como estaba indefensa, la saquearon a satisfacción. Los indios rebeldes, restos de la facción de García, habían engrosado sus poblaciones en la montaña con otros que fueron obligados a seguirlos temiendo los mataran como a tantos que habían resistido. Estos indios continuaron los asaltos sobre los 
pueblos sometidos al gobierno, haciéndoles más o menos daño, hasta 1772 en que se estableció bien la casa fuerte de Yavira, con fuerza suficiente para la seguridad de la Provincia. ${ }^{60}$

1728. Levantamiento de Tadó -Cuarenta negros expoliados por las necesidades matan al minero que los dirigía y a otros catorce españoles, poniendo en gran consternación la Provincia con la noticia de que se levantarían tres mil de las cuadrillas para tomarse el gobierno. El teniente Julián Trespalacios y Mier, debeló la insurrección, castigando con la pena capital a cuatro africanos cabecillas del tumulto. Averiguadas las causas se "halló ser la opresión en que los amos tienen a los esclavos con tan crecido trabajo, castigo y corto alimento, no siendo capaces de mantenerse ni de tener descanso". ${ }^{61}$

1732. El alboroto del Patía -En el gobierno de José Francisco Carreño, se alzaron varios negros y formaron palenque en el sitio de El Castigo, en el valle del Patía. Se intentó reducirlos por la fuerza pero no se pudo, viéndose obligada la Audiencia de Quito a ofrecerles la paz, la libertad y el derecho de vivir allí tranquilos con tal que se sometieran a la vida civil, pero sin admitir otros esclavos prófugos. Aceptada la propuesta, no cumplieron la última condición.

Habiendo crecido la reunión, al mando de un negro llamado Jerónimo, Carreño, en 1745, resolvió someterlos, contraviniendo lo pactado por el gobierno de Quito. Al efecto, una fuerte expedición dirigida por Juan Álvarez de Uría y Tomás Hurtado, hacendados del Patía, atacaron las fortificaciones y trincheras levantadas por los negros. Tomás Alvarado, vecino de Pasto, blanco que se servía de los cimarrones, hecho caudillo por la turba, quedó herido en la refriega y muerto Jerónimo que comandó la gente con piedras y garrotes, lanzas, machetes y fusiles.

El padre franciscano fray José Joaquín Barrutieta, que acompañó la expedición como capellán, por medio de la persuasión y buenos oficios, consiguió que los fugitivos se presentaran y rindieran, y el

\footnotetext{
${ }^{60}$ Ortega Ricaurte, Enrique. Op. cit

${ }^{61}$ Ortega Ricaurte, Enrique. Op. cit.
} 
Rogerio velásquez

Cabildo acordó dar las gracias tanto a él como a Álvarez Uría y a Hurtado por el servicio patriótico y útil que habían prestado. ${ }^{62}$

1754. Otra vez el Darién -Reedificados los pueblos de Molineca, Balsas, Tubcutí, Chucunaque, Cape y Ya visa, destruídos por los corsarios, los indios se rebelaron de nuevo contra los extranjeros.

Empujados por los ingleses, extinguieron los pocos europeos que quedan en el Real de Santa María, logrando dar muerte a 87 franceses que se encontraban en Portobelo, Caimán, Concepción, Cayos de San Blas y Golfo del Darién.

Esta matanza, perpetrada por nativos sobornados, además de detener el avance de la agricultura que había comenzado a florecer, estimuló la codicia de los ingleses que pensaban apoderarse de las costas, de acuerdo con el plan trazado en Londres en 1739.

1758. Motín del Bajo Atrato - "Indios de Tigre y Tarena llevados a Murindó, incendiaron la población de Vigía y dieron muerte al capitán y al fiscal, regresando después a sus antiguas aldeas". ${ }^{63}$

1766. Sedición de Riosucio -En este año el capitán Cabrera, de Calidonia y Ramón, de un río inmediato, incendiaron la vigía de Riosucio, dando muerte al capitán español y a ocho hombres que estaban con él, para robarles. Este ataque volvió a repetirse en 1774, por los capitanes Bernardo, de Estola, y Toví, de Caimán”. ${ }^{64}$

1782. Nueva revuelta del Darién - Indios de Caimán, Concepción y Mandinga,

(...) pasan a cuchillo a 140 hombres del Regimiento de la Corona, que viniendo en su auxilio de Cartagena fueron llevados por un temporal a las costas del Darién. El mariscal de campo don Antonio Arévalo, los sometió en 1786. Para escarmentarlos se dispuso el plan de hostilizarlos por el sur y el norte, con que se quemaron muchos pueblos, se mataron animales, se arrasaron platanales, se aprisionaron bastante de ellos hasta que los redujeron a la última angustia. ${ }^{65}$

\footnotetext{
${ }^{62}$ Aragón, Arcesio. Fastos Payaneses 1536-1936. Bogotá: Imp. Nacional. 1936.

${ }^{63}$ Ortega Ricaurte, Enrique. Op. cit.

${ }^{64}$ Ortega Ricaurte, Enrique. Op. cit.

${ }^{65}$ Pérez Ayala, José Manuel, Antonio Caballero y Góngora. Virrey y Arzobispo de Santa Fe.
} 
1806. Disturbio de Pavarandó - La convención de paz y vasallaje firmada por los indios y el virrey Caballero y Góngora, en 1787, fue incumplida por los naturales al atacar el pueblo de Pavarandó. En esta ocasión fue aniquilado el resto de la guarnición traída por el gobierno para poblar el Darién. ${ }^{66}$

1809. Fusilamiento de don Carlos Ciaurriz -Los informes continuos del gobernador Carlos de Ciaurríz a la Audiencia de Santa $\mathrm{Fe}$, sobre el estado miserable de la tierra y los abusos de los corregidores y empleados con los del estado servil, movió la conjura de Juan de Aguirre, quien, amparado con los vínculos de sangre que lo unían a la virreina de Bogotá, fusiló, sin proceso, al valeroso gobernador, asumiendo Aguirre el comando del territorio.

La impunidad de este atropello exasperó el ánimo del pueblo, que empezó a ver en el sobrino político de Amar y Barbón, un monstruo de soberbia, de iniquidad y de avaricia, a la vez que redobló su esfuerzo por debilitar cada día el poderío de los peninsulares.

Así llegó el Chocó al siglo XIX. Para pacificar la tierra no habían valido pactos con indios, destacamentos, fuertes, vigías, traslados de pueblos y familias de una banda a otra, armas y gobernadores. Por todas partes seguían alentando cimarrones, ingleses, franceses, soldados devorados por el clima, iglesias taladas y sacerdotes sacrificados, pobreza e ignorancia. Como nadie conocía las artimañas de Pitt, la ambición de Bonaparte, el descontento de los mercaderes de Europa, la circulación de panfletos, la declaración de Filadelfia, la noticia de la revolución francesa, los habitantes alentaban un deseo: ser libres los padres, los hermanos, los esposos y sus hijos, vale decir, ser ciudadanos.

1723-1796. Bogotá: Imp. Municipal. 1951.

${ }^{66}$ Ortega Ricaurte, Enrique. Op. cit. 
